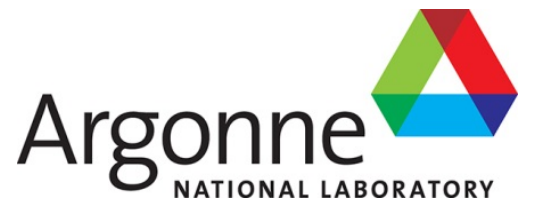

ANL-ART-187

ANL-METL-20

\title{
Mechanisms Engineering Test Loop - Flexicask Design and Testing Report
}

Nuclear Science and Engineering Division 
About Argonne National Laboratory

Argonne is a U.S. Department of Energy laboratory managed by UChicago

Argonne, LLC under contract DE-AC02-06CH11357. The Laboratory's main facility

is outside Chicago, at 9700 South Cass Avenue, Argonne, Illinois 60439. For

information about Argonne

and its pioneering science and technology programs, see www.anl.gov.

\section{DOCUMENT AVAILABILITY}

Online Access: U.S. Department of Energy (DOE) reports produced after 1991 and a growing number of pre-1991 documents are available free at OSTI.GOV (http://www.osti.gov/), a service of the US Dept. of Energy's Office of Scientific and Technical Information.

Reports not in digital format may be purchased by the public from the National Technical Information Service (NTIS):

U.S. Department of Commerce

National Technical Information

Service 5301 Shawnee Rd

Alexandria, VA 22312

www.ntis.gov

Phone: (800) 553-NTIS (6847) or (703) 605-6000

Fax: (703) 605-6900

Email: orders@ntis.gov

Reports not in digital format are available to DOE and DOE contractors from the Office of Scientific and Technical Information (OSTI):

U.S. Department of Energy

Office of Scientific and Technical Information

P.O. Box 62

Oak Ridge, TN 37831-0062

www.osti.gov

Phone: (865) 576-8401

Fax: (865) 576-5728

Email: reports@osti.gov

\section{Disclaimer}

This report was prepared as an account of work sponsored by an agency of the United States Government. Neither the United States Government nor any agency thereof, nor UChicago Argonne, LLC, nor any of their employees or officers, makes any warranty, express or implied, or assumes any legal liability or responsibility for the accuracy, completeness, or usefulness of any information, apparatus, product, or process disclosed, or represents that its use would not infringe privately owned rights. Reference herein to any specific commercial product, process, or service by trade name, trademark, manufacturer, or otherwise, does not necessarily constitute or imply its endorsement, recommendation, or favoring by the United States Government or any agency thereof. The views and opinions of document authors expressed herein do not necessarily state or reflect those of the United States Government or any agency thereof, Argonne National Laboratory, or UChicago Argonne, LLC. 
ANL-ART-187

ANL-METL-20

\section{Mechanisms Engineering Test Loop - Flexicask Design and Testing Report}

Prepared by:

C. Grandy, E. Kent, D. Kultgen, M. Weathered, D. Andujar, and A. Borowski

Nuclear Science and Engineering Division

Argonne National Laboratory

February 2020 



\section{EXECUTIVE SUMMARY}

This report documents the design development and testing of the Flexicask system for the Mechanisms Engineering Test Loop (METL). Currently, METL has completed Phase I construction and has been operating for over a year. The Flexicask system (Figure 1) was designed to allow for the removal and insertion of test articles into a METL test vessel while maintaining an acceptable inert atmosphere to minimize contamination of the METL sodium. This report discusses the design development of the Flexicask system, the commissioning and testing of the system, and the initial use of the Flexicask system to remove the Gear Test Assembly (GTA) from the METL Test Vessel 1.

\section{METL Purpose \& Background}

The successful operation of sodium-cooled fast reactors will largely depend on how well all of the components work within a sodium environment. Therefore, the mission of the Mechanisms Engineering Test Loop (METL) is to provide the infrastructure and technical expertise required to test advanced technologies in a high-temperature sodium environment. In turn, the results gleaned from experiments performed in METL will help to develop state-of-the-art advanced reactors.

The layout of METL follows the characteristic design of a sodium test facility. The facility consists of multiple test loops in which tanks/vessels, valves, and other components are interconnected via piping and tubing. The system is designed to handle both static and flowing sodium which permits each test vessel to be configured to suit the particular needs of an experiment. During operation, the sodium is purified by passing it through the cold trap. Impurity levels can be continuously monitored using the plugging meter. The general design temperature of the facility is $1000\left[{ }^{\circ} \mathrm{F}\right]$ but the maximum design temperature of the 28-inch test vessels is $1,200\left[{ }^{\circ} \mathrm{F}\right]$. As shown below in Figure 2, the design of the METL facility consists of a number of test vessels connected in parallel to a main sodium loop. The different vessels share an expansion tank, purification system, and several electromagnetic (EM) pumps and flowmeters. This flexible, consolidated design minimizes infrastructure requirements and allows multiple experiments to be performed simultaneously.

The METL facility has been fully operational since September 2018 was designed for the testing of small to intermediate-scale components and systems in order to develop advanced liquid metal technologies. Testing different components in METL is essential for the future of advanced fast reactors as it should provide invaluable performance data and reduce the risk of failures during plant operation.

METL also provides development opportunities for younger scientists, engineers, and designers who will ultimately lead the advancement of U.S. high temperature liquid metal technologies. The hands-on experience with METL, both successes and perceived failures; will ultimately lead to better liquid metal technology programs that can support the commercialization of advanced reactors.

Some examples of technologies that can be tested and demonstrated in METL include: 
1. Components of an advanced fuel handling system - Fuel handling systems are used for the insertion and removal of core assemblies located within the reactor vessel. Undoubtedly, these components are essential to the successful operation of fast reactors. For liquid metal applications, fuel handling systems need to work inside the primary vessel and typically penetrate through the cover gas of the primary system. As a result, fuel handling systems must address issues associated with 'sodium-frost' buildup.

2. Mechanisms for self-actuated control and shutdown systems - These components have been conceived by various designers to provide added defense-in-depth for reducing the consequences of beyond-design-basis accidents. These self-actuated control and shutdown mechanisms include devices such as curie-point magnets and fusible linkages.

3. Advanced sensors and instrumentation - Advanced fast reactors contain sensors and instrumentation for monitoring the condition of the plant. Sometimes these components are required to work while immersed in the primary coolant. This category includes but is not limited to, sensors for the rapid detection of hydrogen presence in sodium (which is indicative of a leak), the detection of impurities in the coolant (i.e., improvement of plugging meters or oxygen sensors), alternative methods of leak detection, improved sensors for level measurement and other advanced sensors or instrumentation that improve the overall performance of the advanced reactor system. These improved sensors and instrumentation can be incorporated into an artificial intelligence (AI) and machine learning (ML) testing environment with a digital twin to support advanced AI/ML deployment in advanced reactors.

4. In-service inspection and repair technologies - These systems include visualization sensors for immersed coolant applications and technologies for the welding and repair of structures in contact with the primary coolant.

5. Thermal hydraulic testing in prototypic sodium environment - A thermal hydraulic test loop could be used to acquire distributed temperature data in the cold and hot pools of a small scale sodium fast reactor during simulated nominal and protected/unprotected loss of flow accidents. This testing could allow for the articulation of the heated region in the core to allow for a parametric study of IHX/core outlet height difference and its effect on thermal stratification of sodium in the hot pool. Ultimately this data will be used for validating CFD and systems level code.

As discussed below, the Flexicask system is a vital part of operating the METL facility. This system has undergone design, fabrication, testing, and now operations with the first test article in METL. The work on the 18-inch Flexicask system (which fits the 18-inch METL test vessels) was also used to inform the design of the 28-inch Flexicask which is currently in fabrication. 


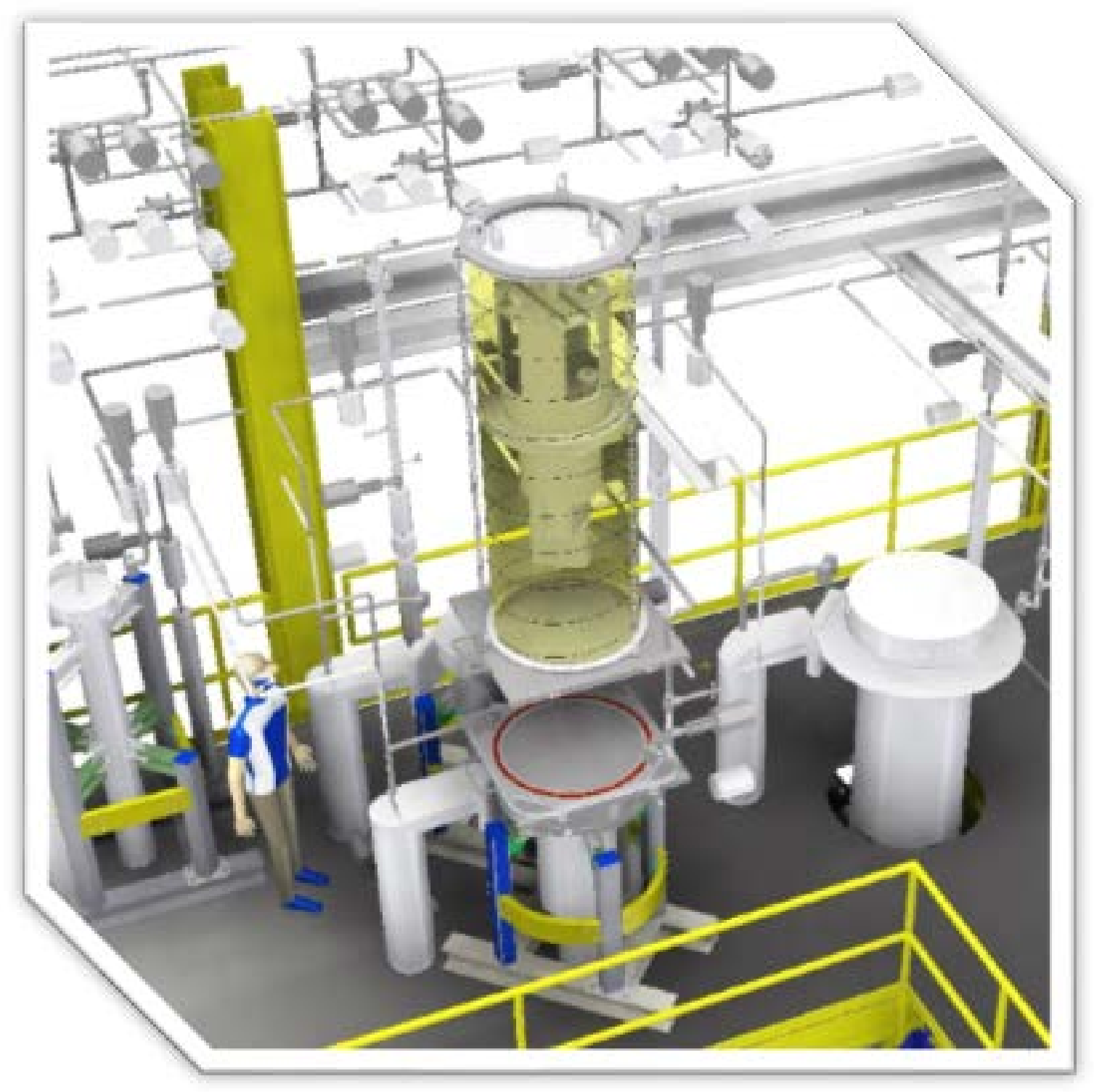

Figure 1 -CAD Model of Flexicask system - shown with test article located at METL Test Vessel 2 


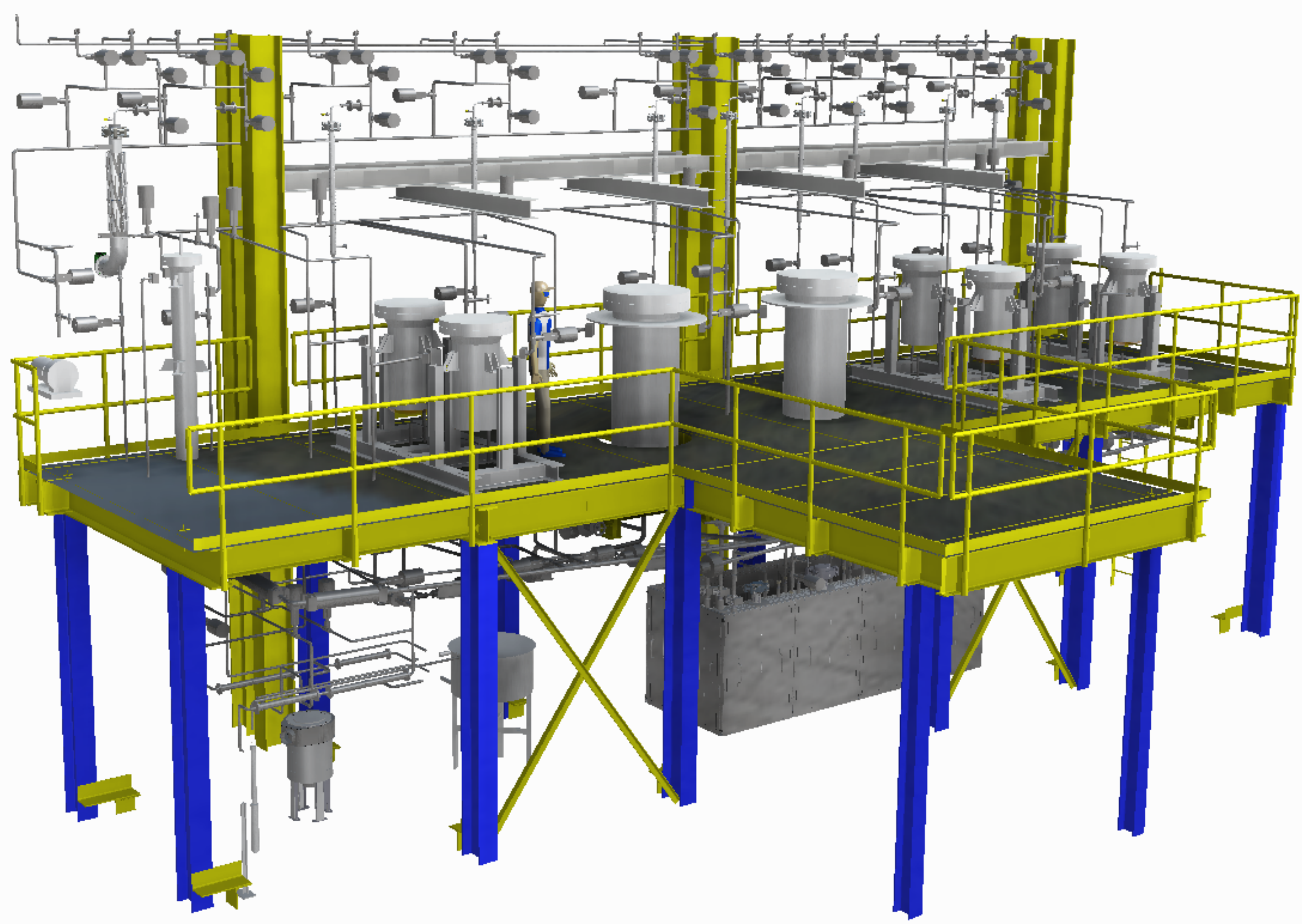

Figure 2-A 3D model of the Mechanisms Engineering Test Loop showing Phase I and four additional test vessels ${ }^{1}$. 


\subsection{Acknowledgement}

This research was sponsored by the U.S. Department of Energy, Office of Nuclear Energy, for the Advanced Reactor Technologies (ART) Research and Development Program under Contract DE-AC02-06CH11357. We gratefully acknowledge the support provided by Tim Beville of DOE-NE, Advanced Reactor Technologies, R\&D Program Manager; Brian Robinson of DOE-NE, Advanced Reactor Technologies, Fast Reactor Manager; and Robert Hill of Argonne National Laboratory, ART R\&D Fast Reactor National Technical Director.

The METL team would like to extend their gratitude to Andrew Borowski who was the predominant design engineer for the METL Flexicask system and many of the METL systems and components. 


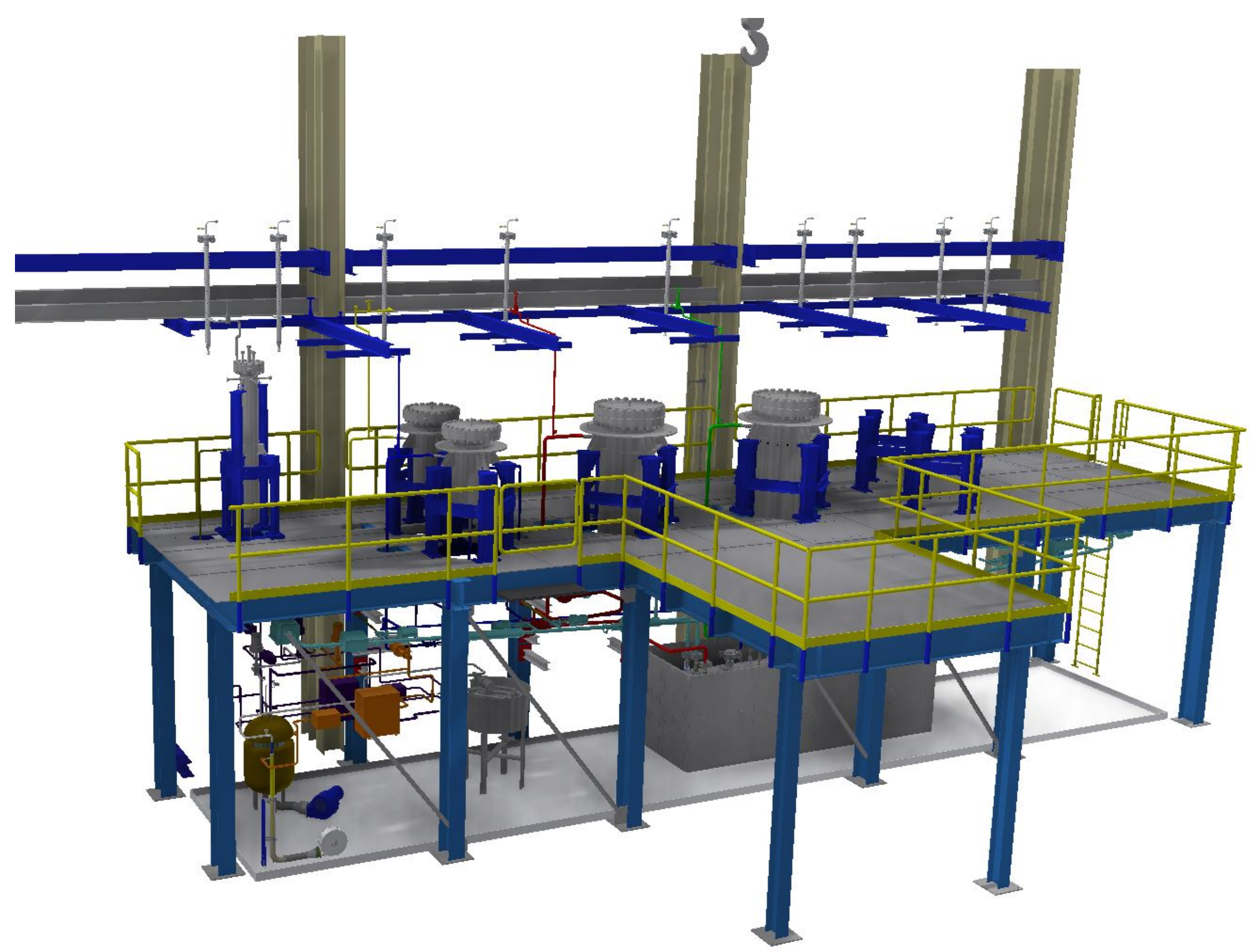

Figure 3-A 3D model of METL after Phase I is complete. ${ }^{2}$

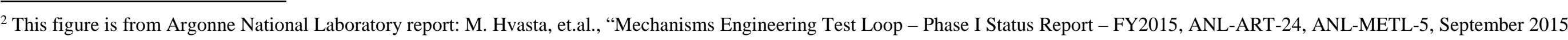




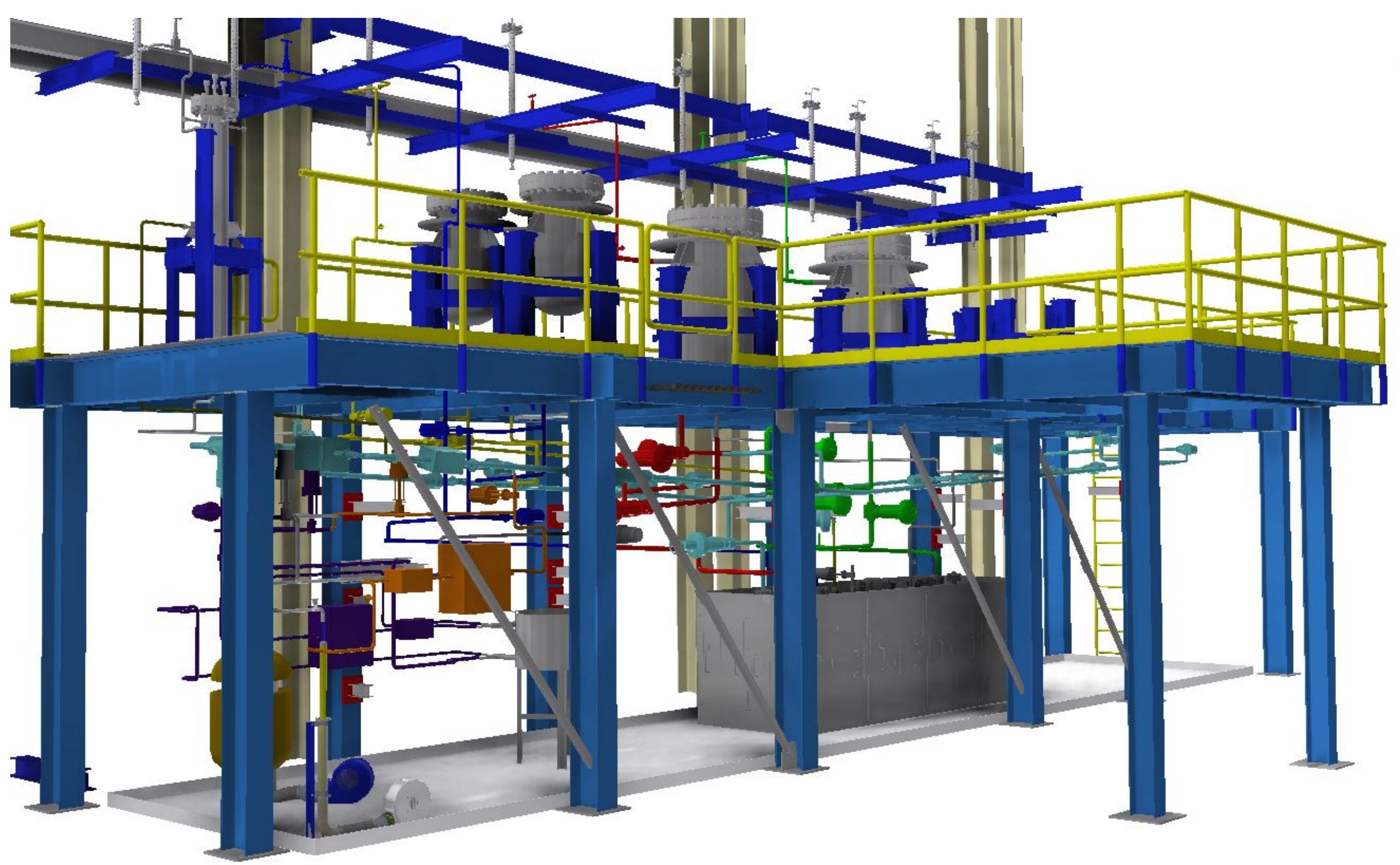

Figure 4 - A 3D model showing the Phase I piping and equipment arrangement underneath the mezzanine. ${ }^{3}$ 


\section{TABLE OF CONTENTS}

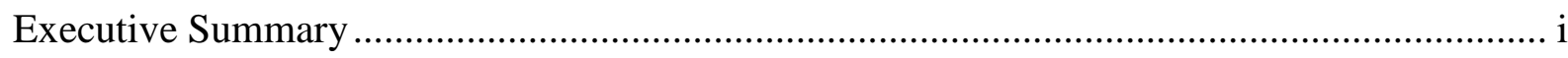

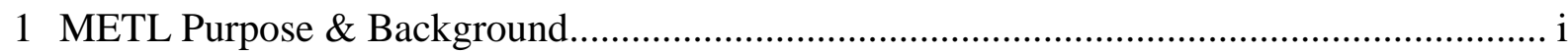

1.1 Acknowledgement ..............................................................................................

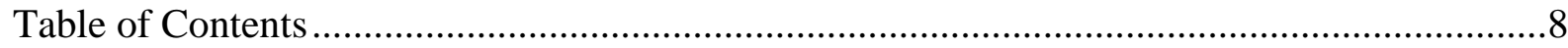

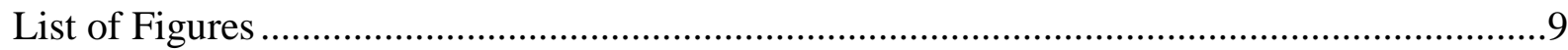

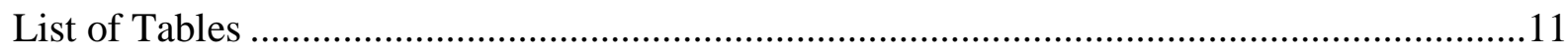

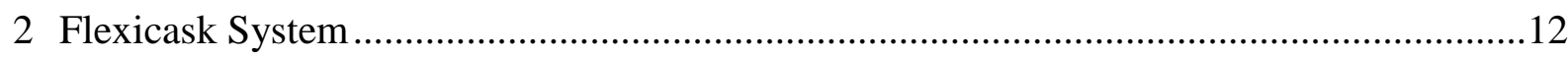

2.1 Flexicask System Design ....................................................................................14

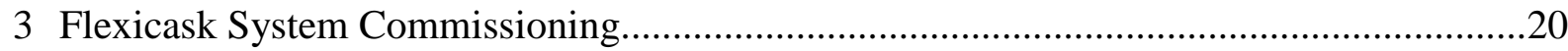

4 Flexicask Operations - Gear Test Assembly (GTA) Removal .............................................30

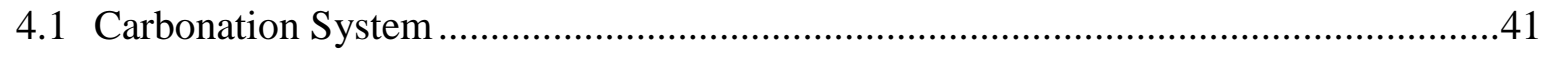

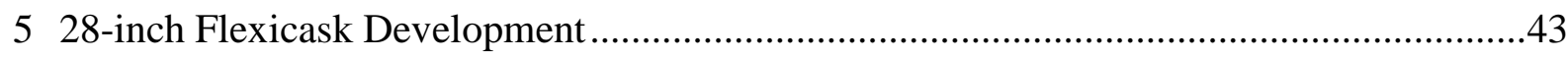




\section{LIST OF FIGURES}

Figure 1 - CAD Model of Flexicask system - shown with test article located at METL

Test Vessel 2

Figure 2 -A 3D model of the Mechanisms Engineering Test Loop showing Phase I and four additional test vessels. .................................................................. iv

Figure 3 - A 3D model of METL after Phase I is complete.......................................... vi

Figure 4 - A 3D model showing the Phase I piping and equipment arrangement underneath the mezzanine........................................................................... vii

Figure 5 - Removal of EBR-II Primary Pump Assembly ............................................. 13

Figure 6 - 18-inch Flexicask Assembly ..................................................................... 15

Figure 7 - A 3D model depicting of Flexicask operation........................................... 16

Figure 8 - A 3D model showing how the Flexicask system will operate above the METL

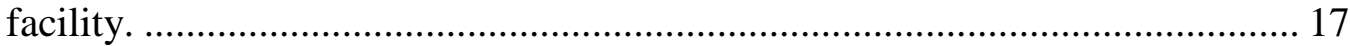

Figure 9 - FlexiCask Demonstration in an older 18-inch test vessel with the larger

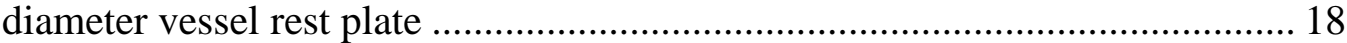

Figure 10 - Closeup View of 18-inch test vessel showing Flexicask support ring ........... 19

Figure 11 - METL Test Vessel 1 with Extensions. METL Test Vessel 2 - shows no support ring extensions .......................................................................... 20

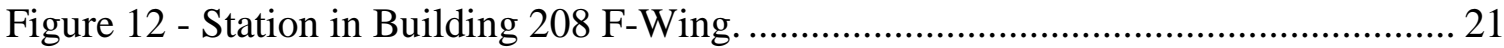

Figure 13 - Fully Assembled Flexicask with Fabric shroud. ......................................... 22

Figure 14 - Flexicask System with Ports Identified.................................................... 24

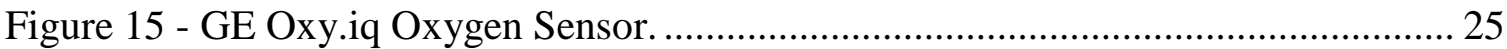

Figure 16 - Flexicask Testing Valve Manifold. ............................................................ 25

Figure 17 - Polyurethane Shroud with Glove Ports. ................................................... 27

Figure 18 - Flexicask Testing with Polyurethane Shroud.............................................. 28

Figure 19 - Flexicask Lifting Blank Flange using the GTA imitator.............................. 29

Figure 20 - Flexicask with Polyurethane Shroud sized to GTA. ................................... 30

Figure 21 - Flexicask positioned over the GTA........................................................ 33

Figure 22 - Flexicask Installed on Test Vessel 1 aligning platen to GTA. ...................... 34

Figure 23 Mounting Hardware Secured through the Flexicask top platen to GTA. Motors and some other components were removed from the GTA prior to this step.... 35

Figure 24 - Flexicask system was sealed to the test vessel and inerted prior to GTA

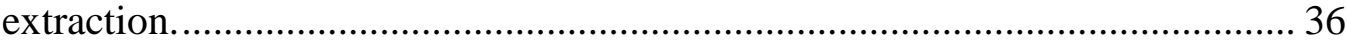

Figure 25 - Flexicask fully extended with GTA fully removed from the 18-inch test vessel and into the inerted shroud (notice there is very little oxidation of the residual sodium).

Figure 26 - Flexicask with GTA inside and separated from Test Vessel 1. Both gates are closed maintaining the inert atmosphere inside the flexicask and inside the test vessel.

Figure 27 - Flexicask with the GTA in transit to Carbonation System............................ 39 
Figure 28 - Flexicask with GTA being positioned over the Carbonation system tank .....40

Figure 29 - GTA installed in Carbonation System with the bottom portion of the flexicask shown sealed to the 18-inch to 28-inch adaptor.

Figure 30 - A P\&ID for the carbonation system. ( $M=$ manual valve, $\mathrm{S}=$ solenoid valve).

Figure 31 - A photo of the completed bubbler for the carbonation system. Carbon dioxide enters through the bottom of the system. Electric heaters are used to raise the temperature of the water to facilitate increasing the humidity of the water. ......42

Figure 32 - Reaction Chamber (left) Connected to Bubbler (right)................................43

Figure 33 - Design Drawings for 28-inch Flexicask Assembly . .44 


\section{LIST OF TABLES}

Table 1 - Initial Flexicask Testing with Fabric Shroud ............................................... 26

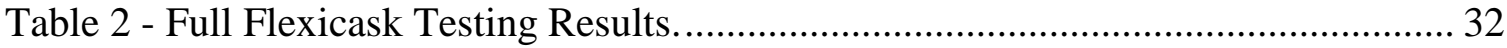




\section{Flexicask System}

During the design development of the METL facility, the engineers had to address the requirement to reduce the amount of impurities that may migrate into a test vessel during the removal and insertion of a METL test article.

During the removal of sodium coated components and hardware from a reactor system, control of the surrounding atmosphere must be maintained to prevent excessive oxidation of the sodium and/or formation of caustic agents which could damage the component and thereby void its further use in the reactor. This coolant contamination issue needs to be addressed for most advanced reactor coolants such as, sodium, $\mathrm{NaK}$, lead, lead-bismuth eutectic, salts, and helium, because the entrainment of atmospheric contaminants can cause the coolant to be out of specification and accelerate the damage to reactor systems and components.

During the design development of the Experimental Breeder Reactor-II, the design for removal of reactor components was taken into account. Steel inert-atmospheric enclosures (Figure 5), called caissons, were engineered into the overall EBR-II design to ensure that components (that are designed to be maintained) can be removed from the reactor vessel while the primary sodium is maintained in a molten state ${ }^{4}$.

Similarly, the METL facility test vessels had to be designed to interface with our Flexicask system for the removal and insert of test articles. However, unlike EBR-II primary system tank, our test vessels can be drained (independently from the main loop) and the temperature can be reduced to allow for hands on operations. In addition, the components removed from METL will not be radiologically activated, and thus the inert-atmospheric enclosure does not require any radiation shielding to protect the workers. Thus, our Flexicask materials of construction could be made from materials which did not have to accommodate high temperatures or high radiation levels, but yet need to provide adequate sealing function.

\footnotetext{
${ }^{4}$ The following three references provide some good background information on the maintenance and servicing of sodium equipment designed and used at EBR-II - R. A. Washburn, "EBR-II Facility for Cleaning and Maintenance of LMR Components”, 1986, paper submitted for presentation at American Nuclear Society, Topical Meeting on Nuclear Power Plant Maintenance, March 23-27, 1986; J. R. Davis, et. al., "Operating Experience with Sodium pumps at EBR-II”, ANL/EBR-027; and B.C. Cerutti, et. al., "Removal and Repair of EBR-II Primary Sodium Pump No. 1”, ANL-7835.
} 


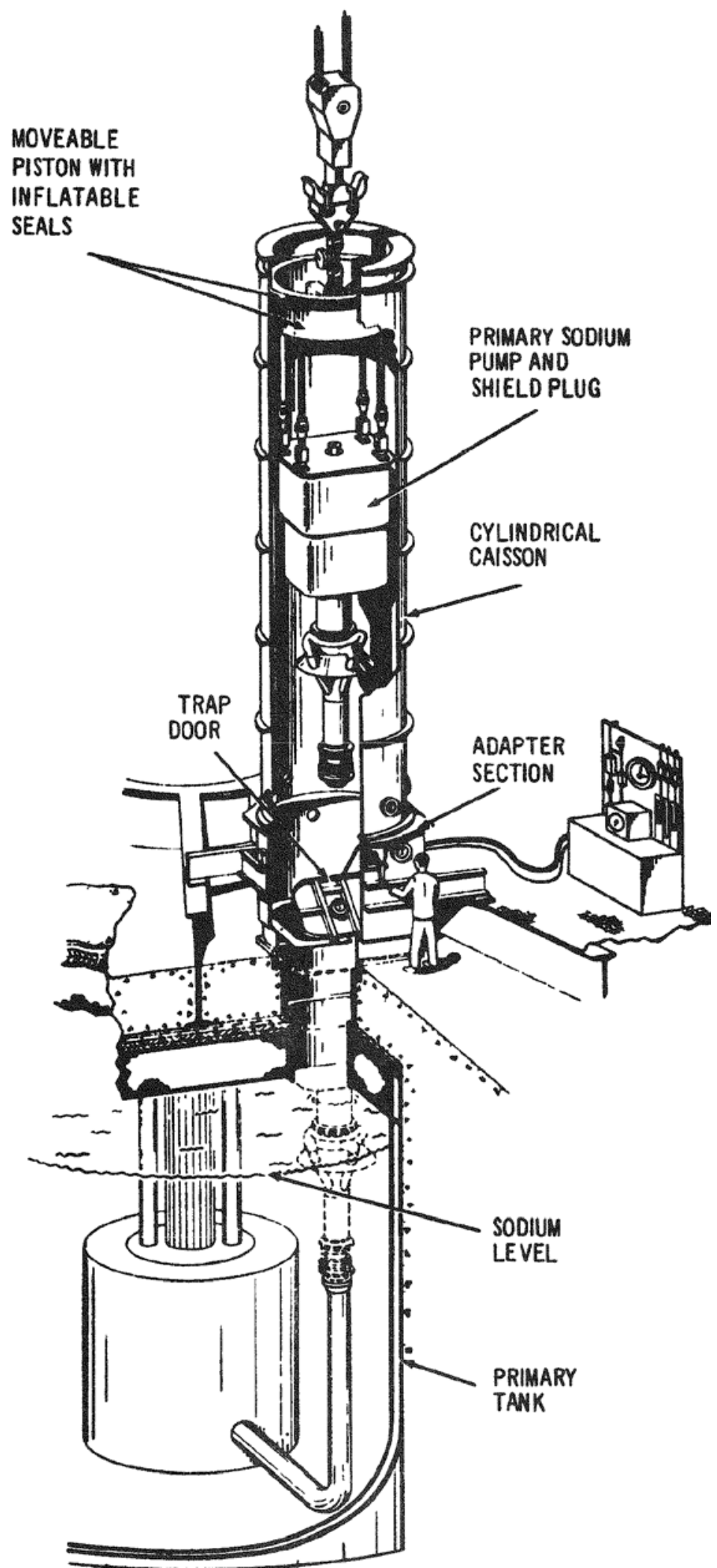

Figure 5 - Removal of EBR-II Primary Pump Assembly 


\subsection{Flexicask System Design}

As mentioned above, during the design of the METL facility, the METL Team had to design a method to remove test articles from a drained and cold inerted test vessel to minimize contaminant entrainment in the test vessel which would have to be subsequently removed by cold trapping.

Figure 6 shows the overall design of the 18-inch Flexicask prototype that was initially conceived, fabricated, and tested. The Flexicask mates and seals to a "support ring" that is welded to each of the 18 and 28 inch vessels and is located right below the test vessel flange.

The Flexicask system consists of the following components:

1. Top support assembly

2. Duct

3. Upper Gate Assembly

4. Seal Plate

5. Lower Gate Assembly

6. Chain Lanyard

7. Hoist rings with platen

8. Miscellaneous fittings

The top support assembly is used to lift the overall Flexicask assembly (via a crane) when it does not include a test article. The chain lanyards are used to tie the top support assembly to the two gate assemblies during transport and to support the weight of the two gate assemblies while minimizing any vertical forces on the duct material. The duct material is attached and sealed to the top support assembly and the upper gate assembly using a silicone O-ring.

The Flexicask interfaces with a test vessel at the test vessel support ring. Originally, this support ring was larger in diameter but would have caused excessive force on the test vessel during heat-up and so the design was changed to a smaller diameter support ring which could easily fit under the test vessel insulation. In addition, physical space was required around the vessels to ensure that the Flexicask system would not interfere with or damage the argon inert gas supply lines and vents lines that are located around the vessels ${ }^{5}$.

\footnotetext{
${ }^{5}$ In a similar manner, when designing an advanced reactor, space is needed on the reactor head for the enclosures that will be used to remove components from the reactor plant. This space needs to be designed into the overall reactor plant design for in-service inspection and maintenance.
} 


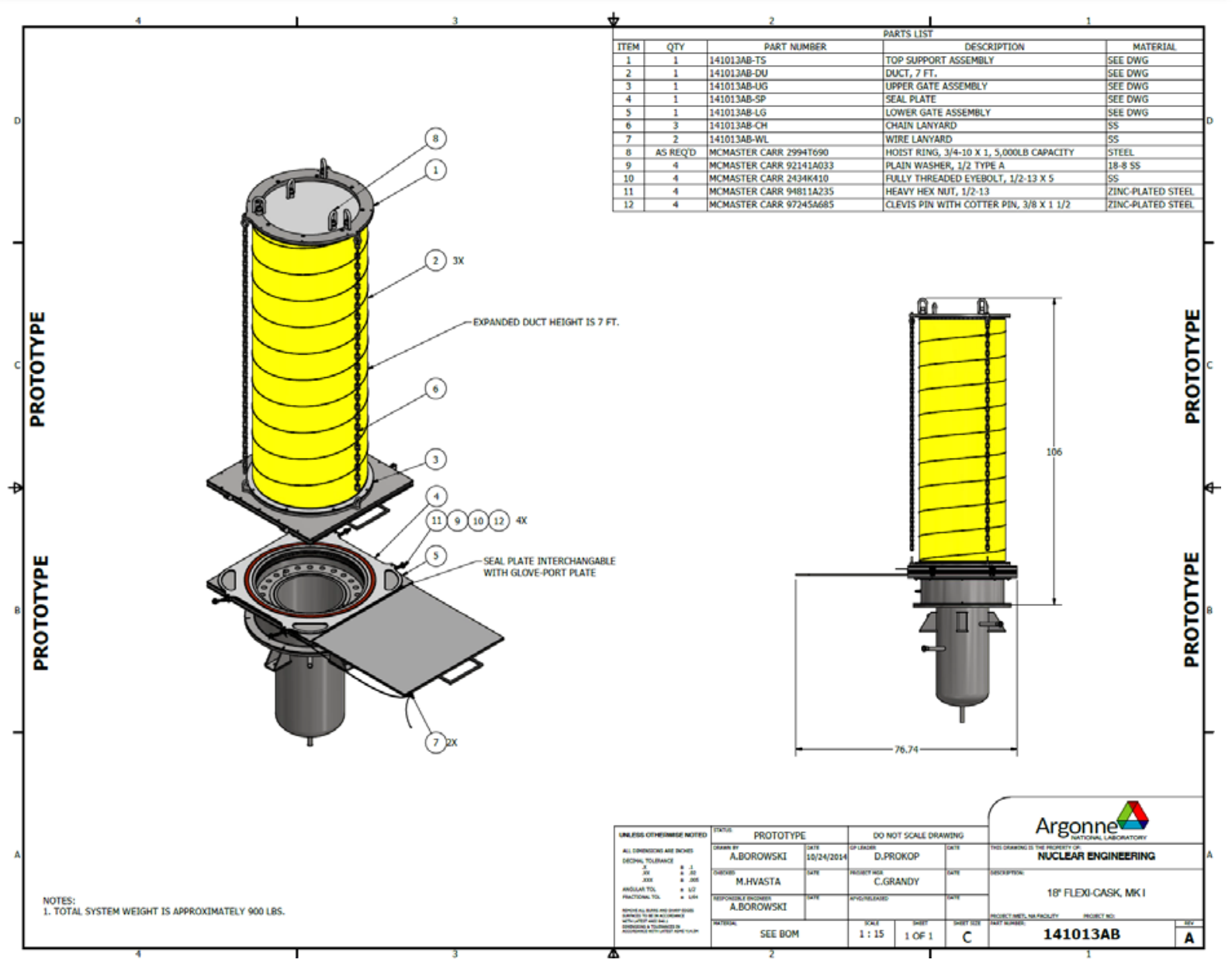

Figure 6 - 18-inch Flexicask Assembly

The following are the general steps for the removal of a component from METL test vessel (Figure 7):

1. The support plate is attached to the test article for lifting using the designed lifting points. This plate may be unique (with specific hole patterns) aligned to the lifting points of the test article.

2. The Flexicask is lowered over the test article with doors removed. In this condition, the bolts that hold the test article flange to the test vessel have been removed.

3. The test article support flange is fastened to the cask top ring

4. The crane is removed from the cask support ring and attached to the test article lifting points that are bolted through the top support plate to the test article. The Flexicask is sealed to the test vessel support ring.

5. The test article is lifted into the Flexicask shroud and gates are installed and closed.

6. The eyebolts holding the two gates together are loosened and moved to the open position to separate the two gates. The two gates are separated with the top gate sealing the 
Flexicask and test article from the air atmosphere and the bottom gate sealing the test vessel. The steps are repeated for inserting a test article into a test vessel.

Note - the lifting apparatus and appurtenances are not shown in the figure.

As shown below in Figure 7, the Flexicask system is lowered onto the vessels. The volume within the Flexicask is kept inerted using a constant argon purge. The Flexicask system will operate using the pre-existing crane in the Building 308 high bay, as shown in Figure 8.

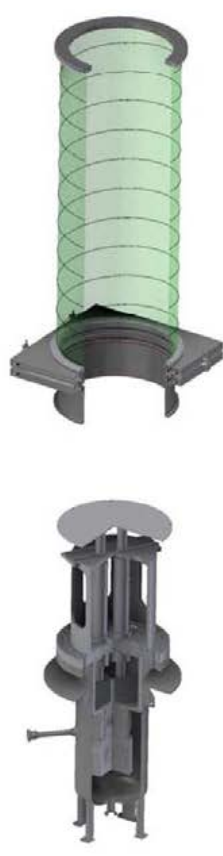

1

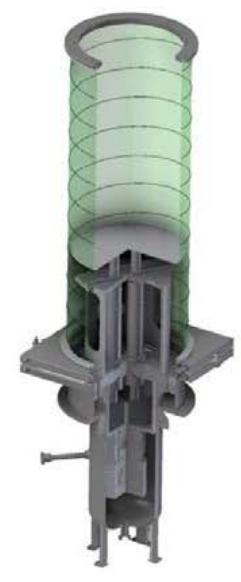

2

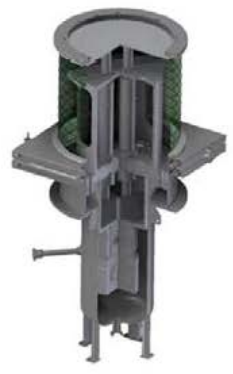

3

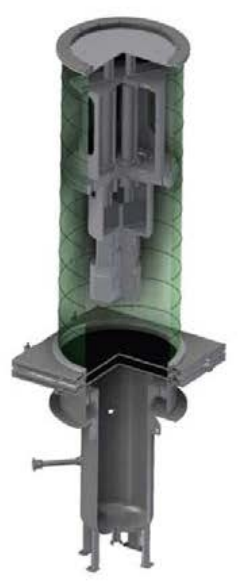

5
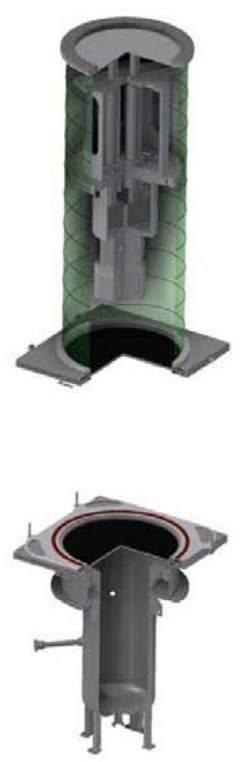

6

Figure 7 - A 3D model depicting of Flexicask operation. 


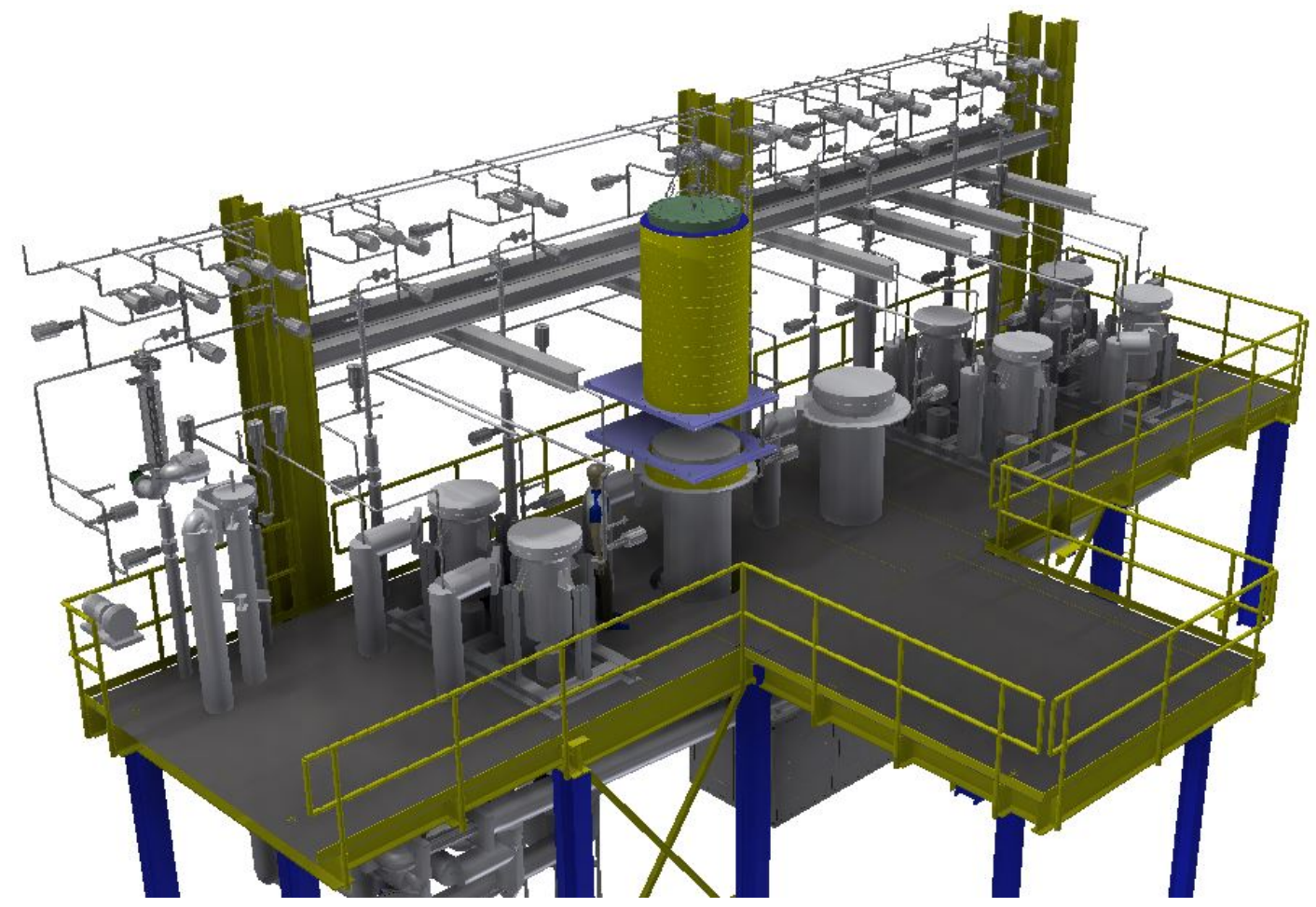

Figure $8-A 3 D$ model showing how the Flexicask system will operate above the METL facility. ${ }^{6}$

The Flexicask required some minor modifications once received from the outside vendor. These alterations were performed by Argonne’s Central Shops and the Flexicask assembly was completed. Initial tests to measure the Flexicask's ability to retain argon gas during different scenarios were also conducted.

\footnotetext{
${ }^{6}$ This figure is from Argonne National Laboratory report: D. Kultgen, et.al., "Mechanisms Engineering Test Loop - Phase I Status Report - FY2016, ANL-ART-73, ANL-METL-9, September 2016.
} 


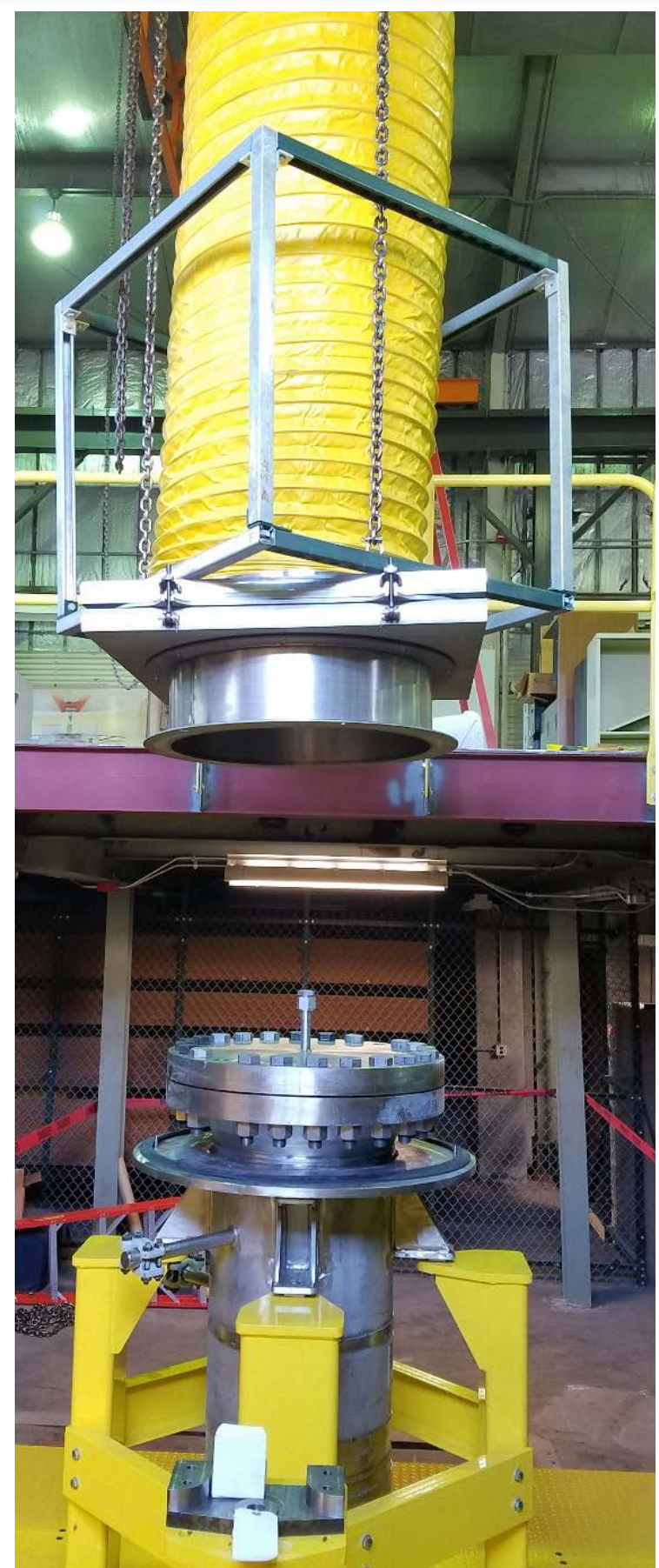

Figure 9 - FlexiCask Demonstration in an older 18-inch test vessel with the larger diameter vessel rest plate ${ }^{7}$

As discussed above, the Flexicask support ring diameter located on the test vessels was reduced to alleviate excessive stress that could occur when the vessel was heated. However, the smaller diameter rest plate (Figure 10) could no longer support the Flexicask. Therefore, extensions to the support ring were designed and fabricated to be installed while the vessel is cold so the Flexicask could be used and then removed once the vessel is ready to be heated. A

\footnotetext{
${ }^{7}$ This figure is from Argonne National Laboratory report: D. Kultgen, et.al., "Mechanisms Engineering Test Loop - Phase I Status Report - FY2018, ANL-ART-148, ANL-METL-14, September 2018.
} 
support ring extension installed versus the permanent rest plate is illustrated below in Figure 11.

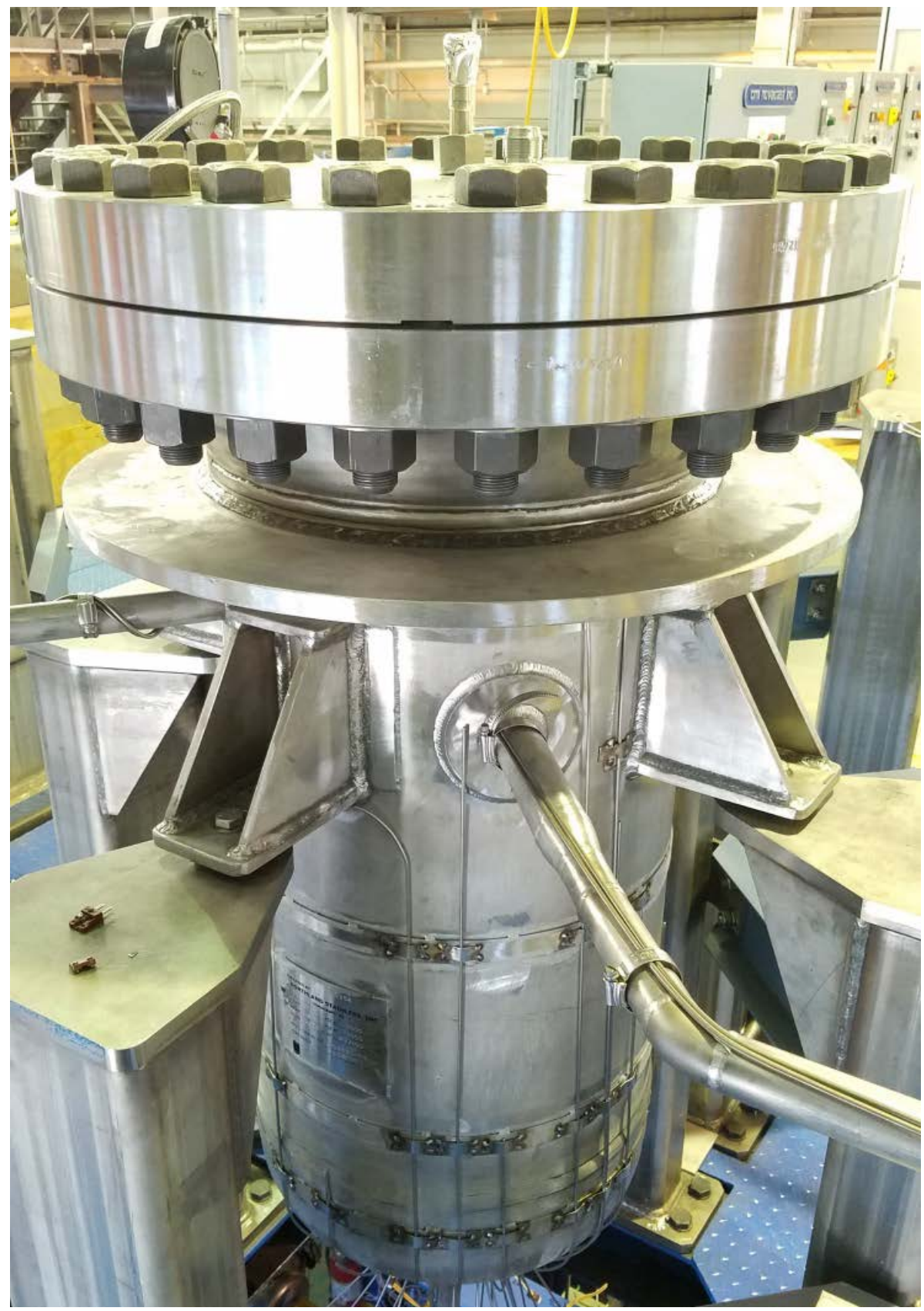

Figure 10 - Closeup View of 18-inch test vessel showing Flexicask support ring 


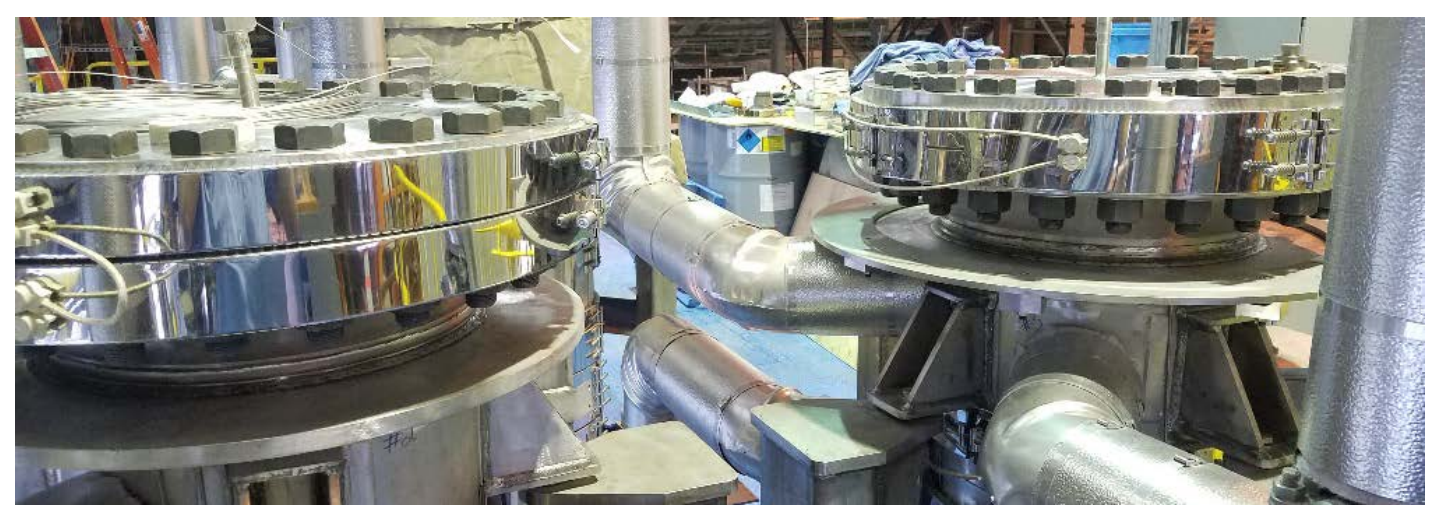

Figure 11 - METL Test Vessel 1 with Extensions. METL Test Vessel 2 - shows no support ring extensions

\section{Flexicask System Commissioning}

Preliminary commissioning of the Flexicask system began in F-Wing of building 208 after all the components were received from the manufacturer. F-Wing was chosen as the preliminary testing ground as location that had a prototypic 18 -inch test vessel available. All rigid components of the Flexicask were made of 304 stainless steel, and any elastomer seals were made of silicone to ensure all materials were compatible with sodium. The only exception to this was the flexible shroud that would surround the test article. The original design used a reinforced fabric enclosure with a steel coil woven into the fabric that helped to keep the shroud on a single axis as it collapsed. Figure 12 shows the 18-inch test vessel located in FWing. Figure 13 shows the Flexicask fully assembled and secured to the overhead crane. There is a Unistrut frame resting on the upper gate to prevent the Flexicask shroud from fully collapsing during this testing. 


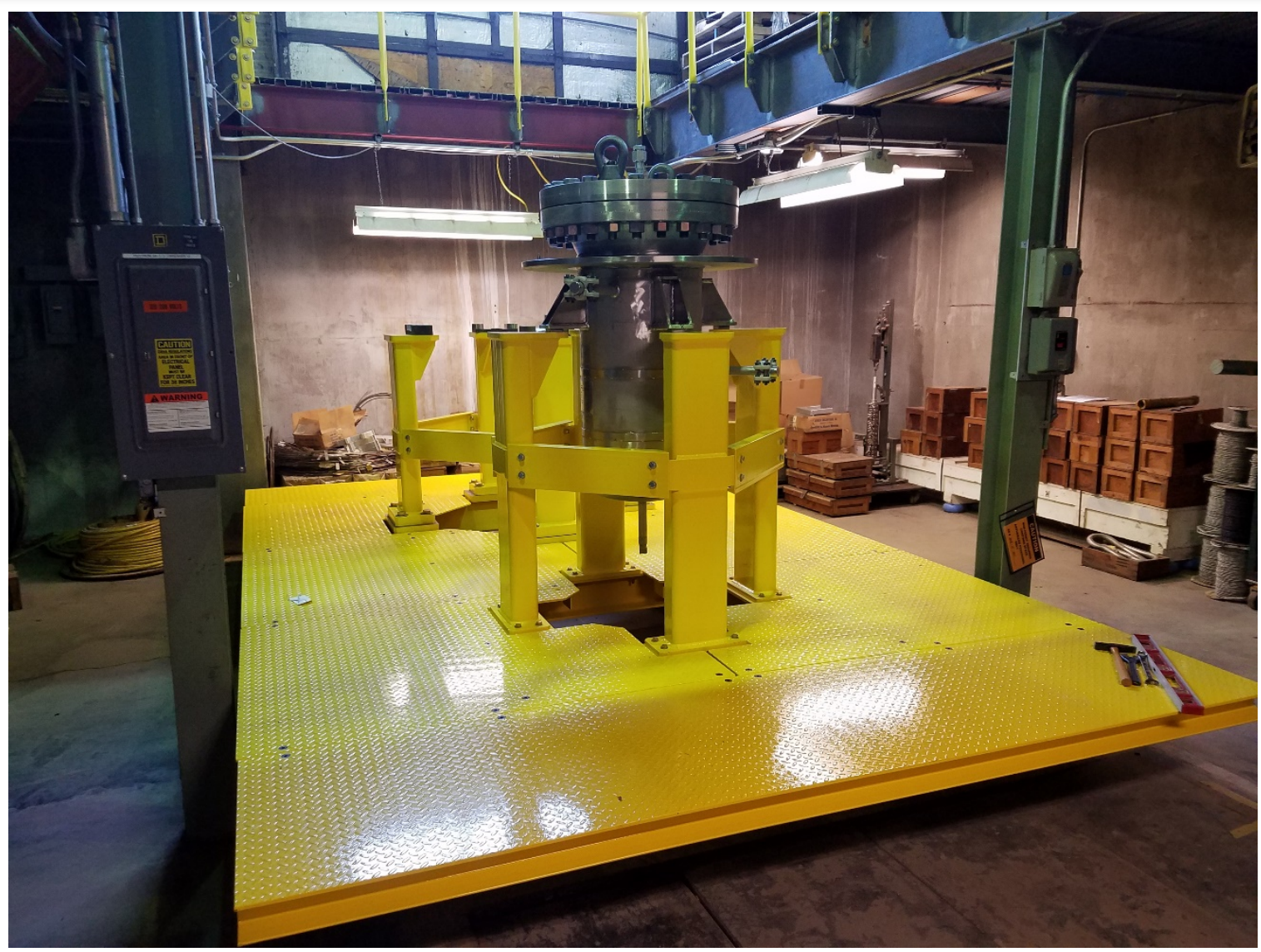

Figure 12 - Station in Building 208 F-Wing. 


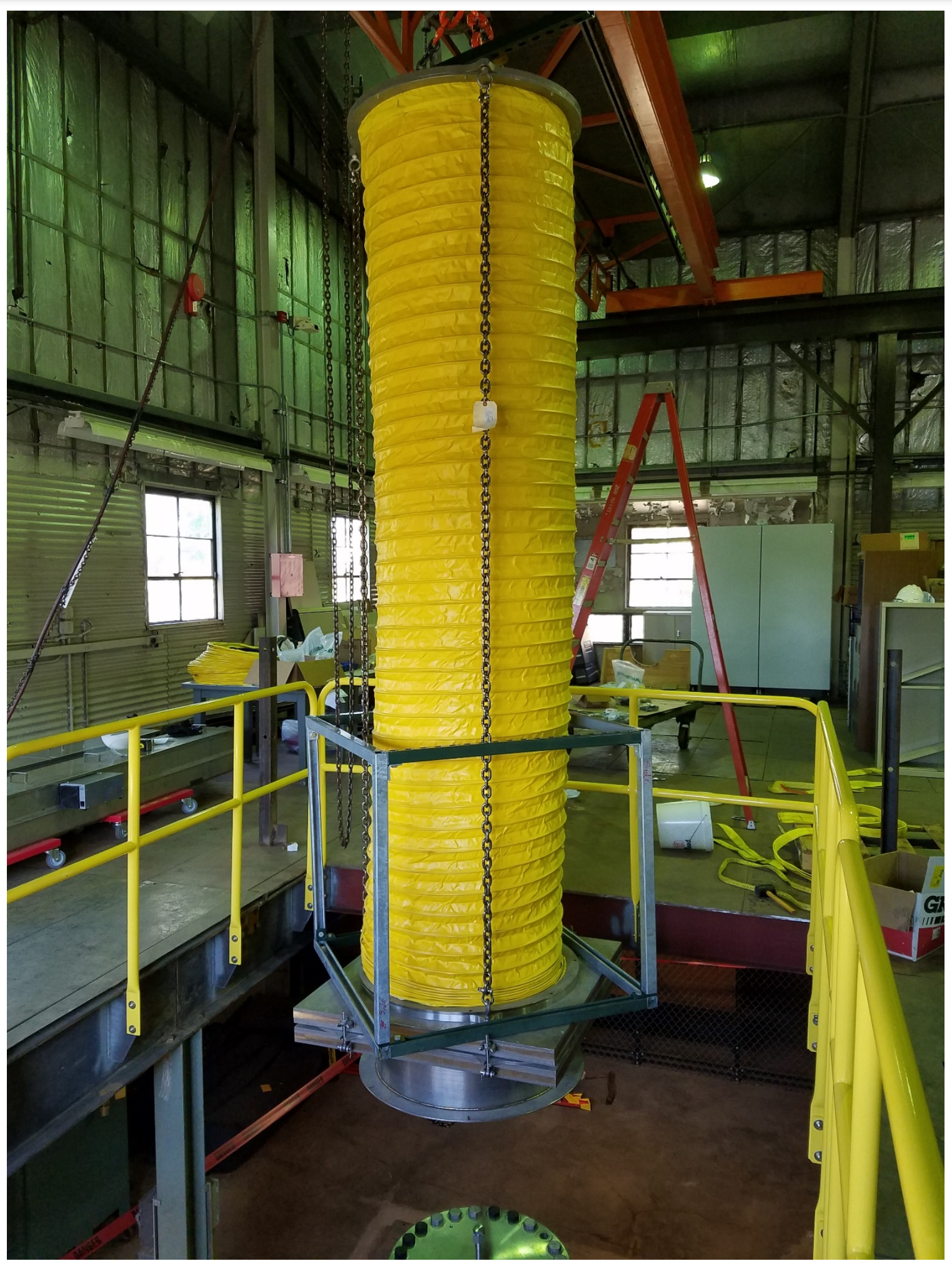

Figure 13 - Fully Assembled Flexicask with Fabric shroud. 
As discussed above, the primary function of the Flexicask is to maintain an inert environment when manipulating test articles. Therefore, the first tests examined how well the system could be sealed. This was accomplished by pressurizing the system with argon while it rested on the support ring of the test vessel, then measuring the oxygen concentration of the gas exiting the system. There are three zones, each with two ports, where argon can be supplied and exhaust gas can be monitored. The first zone is at the top of the shroud on the support plate. The second zone is at the transfer weldment. The third zone is the vessel itself. Figure 14 shows an overview of the system.

Argon was supplied to the Flexicask system to displace any atmosphere, and measurements of the oxygen content at the three available ports were taken as shown in Figure 14. This was tested in four cases:

1. The Flexicask installed on a sealed 18-inch test vessel with the shroud completely compressed. Argon was supplied to Port A and Port B with continuous oxygen sampling at Port A and Port B.

2. The Flexicask installed on a sealed 18" test vessel with the Shroud extended 72". Argon was supplied to Port A and Port B with continuous oxygen sampling at Port A and Port B.

3. The Flexicask extended with the test vessel lid removed and positioned within the shroud and the lower gate closed. The Transfer Weldment was left installed on the test vessel with the gate closed. Argon was supplied to Port A, Port B, and Port C with continuous oxygen sampling at Port A, Port B.

4. The Flexicask extended with the test vessel lid removed and positioned within the shroud and the lower gate closed. The Transfer Weldment was left installed on the test vessel with the gate closed. Argon was supplied to Port A, Port B, and Port $\mathrm{C}$ with continuous oxygen sampling at Port A, Port C. 


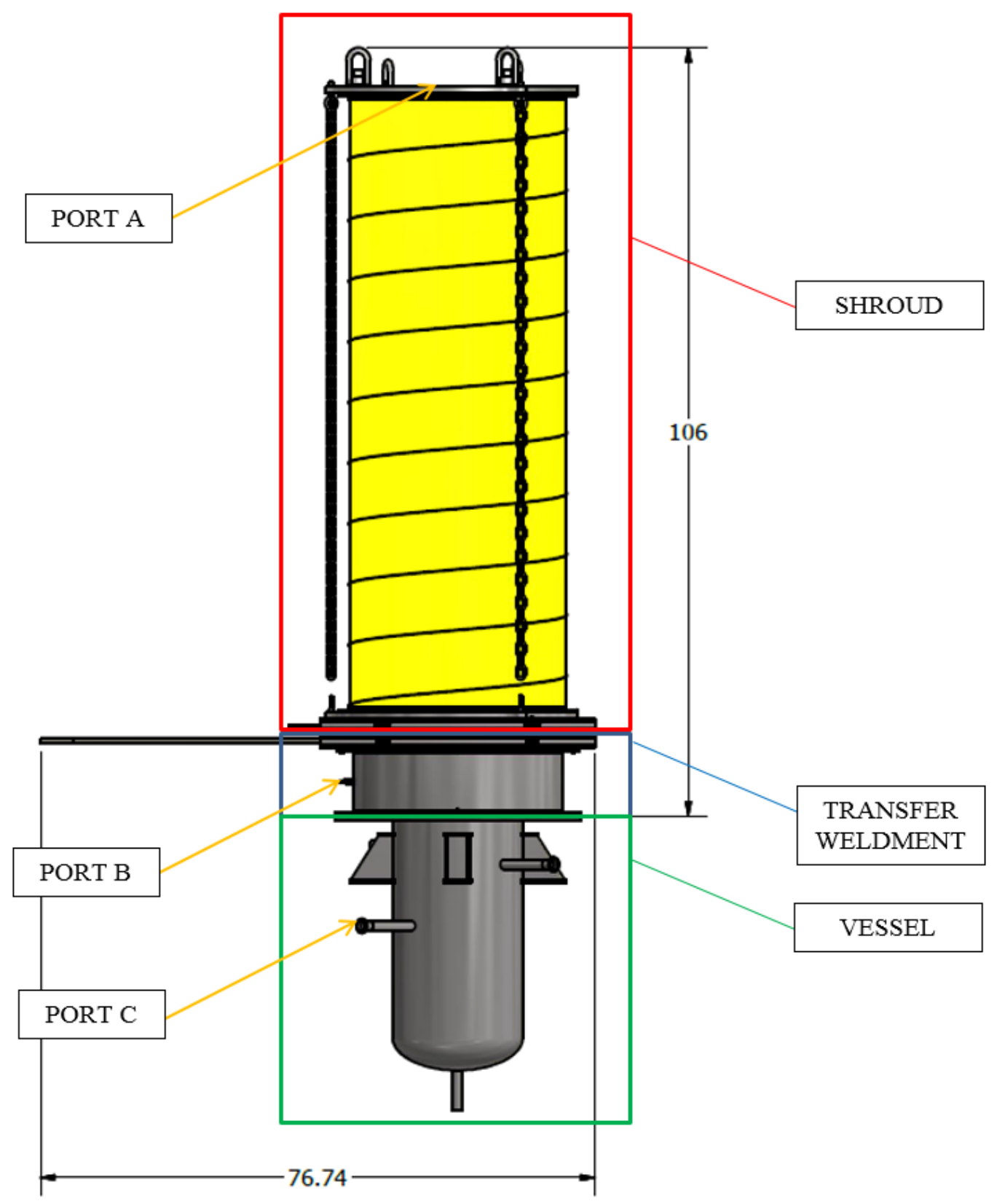

Figure 14 - Flexicask System with Ports Identified.

GE Oxy.iq portable gas analyzers were procured to measure the oxygen concentrations of the exhaust gases. These sensors are capable of measuring oxygen concentrations down to the 0.1-10ppm level. A control test was performed to determine the oxygen concentration of the argon gas supply coming from the METL microbulk. Argon was bled through the sensor until a minimum value of $0.1 \mathrm{ppm}$ oxygen was observed. This verified the performance of the sensors, as well as the purity of the argon supply. Figure 15 shows the sensor used during this testing. Note that the image was taken before the minimum value was reached, so the higher reading can be ignored. 


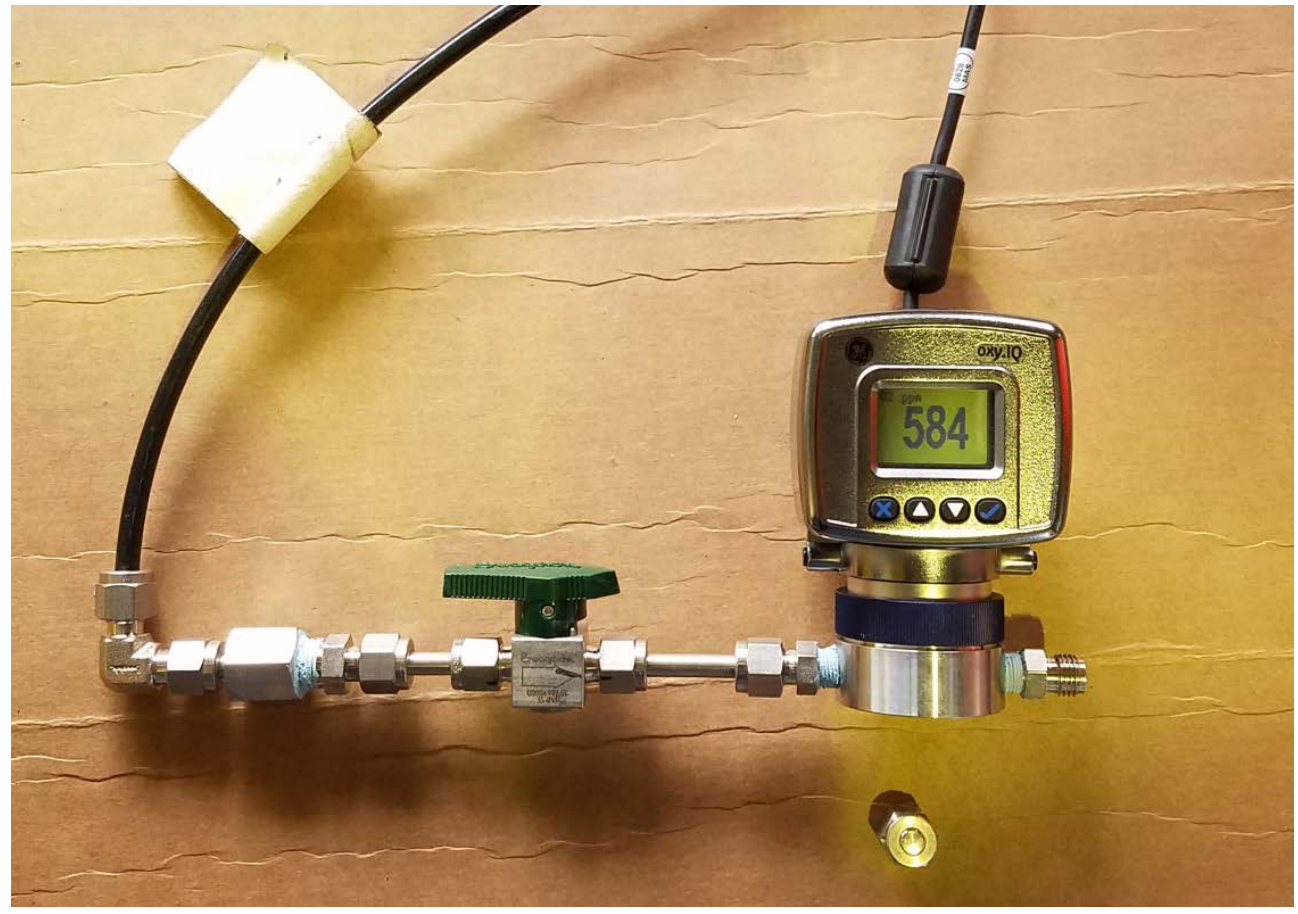

Figure 15 - GE Oxy.iq Oxygen Sensor.

Two of these sensors were used during the preliminary testing. Argon was supplied at the top port as well as the transfer weldment port. Gas flow was controlled using a valve manifold, shown in Figure 16.

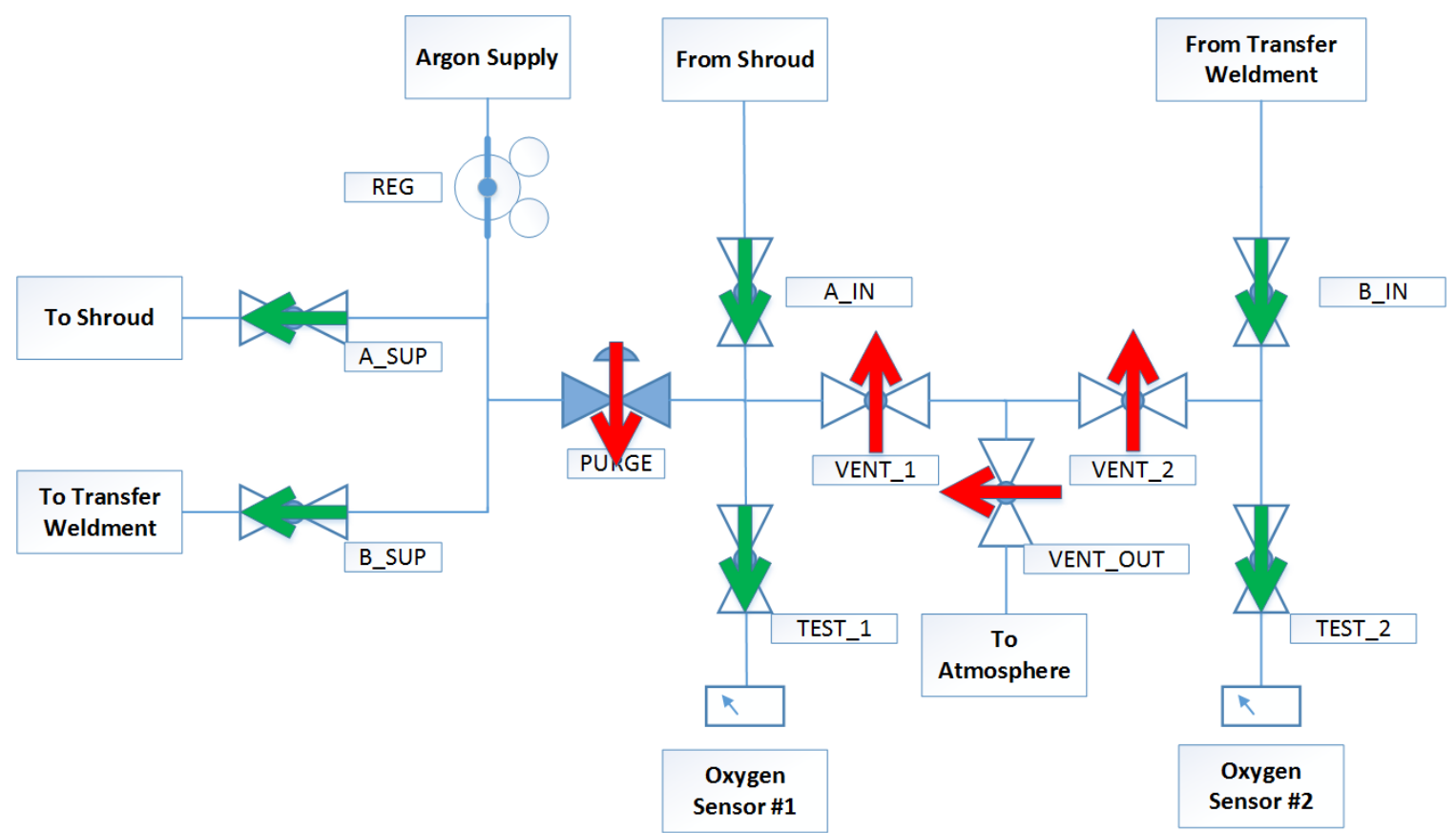

Figure 16 - Flexicask Testing Valve Manifold. 
The results of this testing are shown below and are reported as measured oxygen content. Each test consumed roughly half an Airgas bottle of argon and had a duration of roughly 5 minutes.

Table 1 - Initial Flexicask Testing with Fabric Shroud

\begin{tabular}{|l|r|r|r|}
\hline \multicolumn{1}{|c|}{ Case } & A & B & C \\
\hline 1 & $<50 \mathrm{ppm}$ & $<10 \mathrm{ppm}$ & - \\
\hline 2 & $<10,000 \mathrm{ppm}$ & $<10 \mathrm{ppm}$ & - \\
\hline 3 & $<19 \%$ & $<60 \mathrm{ppm}$ & - \\
\hline 4 & $<19 \%$ & - & $<10 \mathrm{ppm}$ \\
\hline
\end{tabular}

These results suggest that the Flexicask system sufficiently inerts the Transfer Weldment and the Test Vessel during operations, but insufficiently inerts the Shroud.

Oxygen readings at the top of the shroud never dropped below $1 \%$ concentration. Oxygen readings at the transfer weldment did drop below $100 \mathrm{ppm}$, but this was likely due to the fact that argon is heavier than air and will sink and displace oxygen. The main source of the argon leak was determined to be the shroud itself. As the fabric was sewn together, the gas was able to bleed out of the stitching. It was determined that a new shroud design was needed.

Before a new shroud was procured, tests were conducted to see how well the Flexicask could manipulate a test article. These tests used the blank flange on the test vessel. These test were also unsuccessful as the mounting hardware could not be fastened to the flange easily due to the fact the shroud was opaque and workers could not see inside. Additionally, once the flange was secured, workers were not capable of fitting the flange back on the test vessel without see inside the shroud. This further justified a change in the shroud design.

A polyurethane custom glove bag was designed and procured to replace the original fabric shroud. Polyurethane was determined to be sufficiently compatible with the system as the shroud would come in contact with cold frozen sodium, and only in small quantities. The polyurethane shroud has the advantage that it is transparent, so workers can see inside while they are working. The polyurethane shroud also has the advantage of being fully sealable with no stiches or leak paths. Figure 17 shows the polyurethane shroud design. 


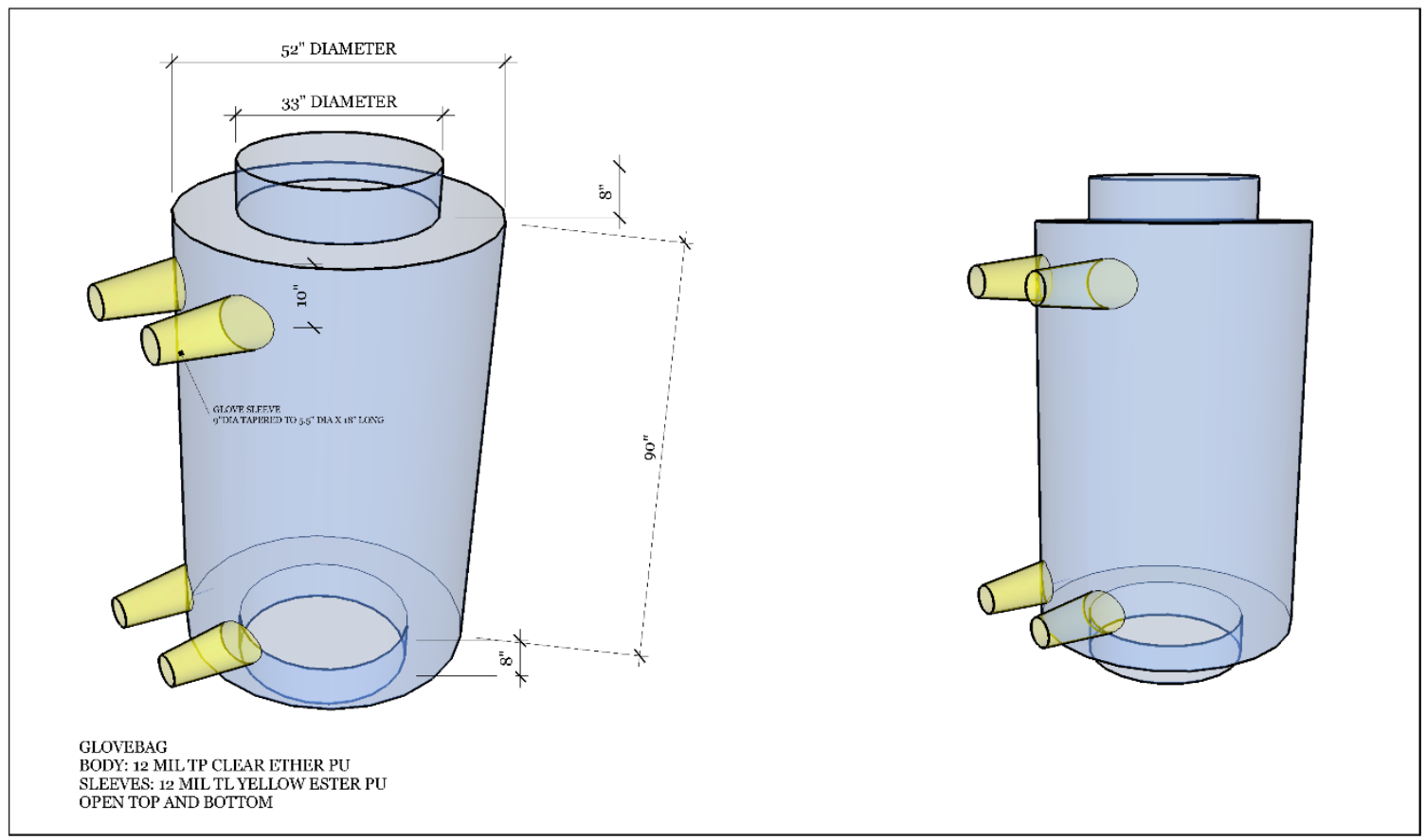

Figure 17 - Polyurethane Shroud with Glove Ports.

No modifications were needed to fit this shroud, so testing began once the material was on hand. The same testing was performed with the polyurethane shroud as the fabric shroud, and results were significantly improved. The system was able to be fully sealed, and oxygen readings at the top port and transfer weldment port dropped below 5ppm. Figure 18 shows the Flexicask during this testing. Note that this testing was performed in Building 308, where the Carbonation System could be used as an 18-inch test vessel mock. 


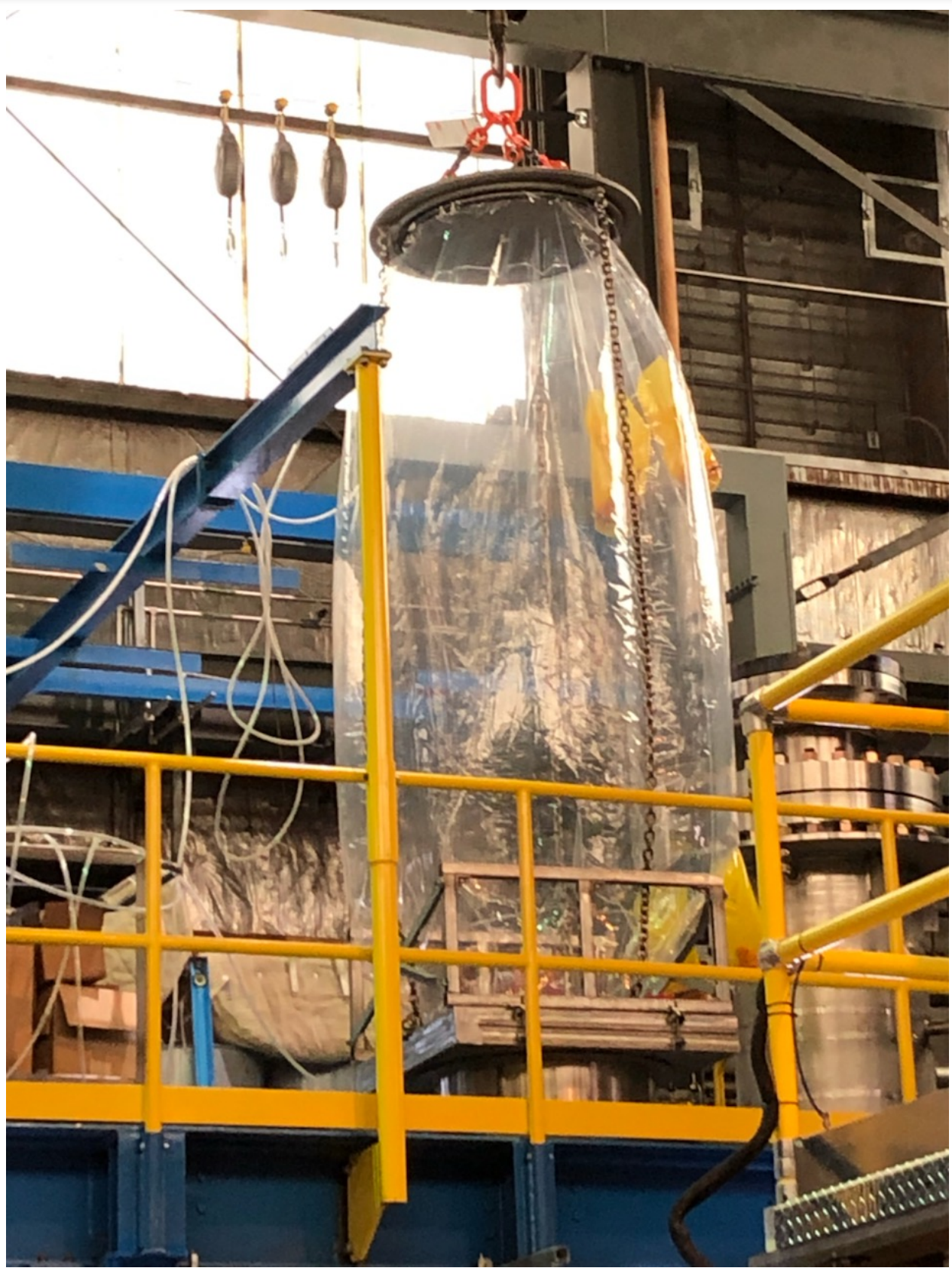

Figure 18 - Flexicask Testing with Polyurethane Shroud.

The next test attempted was to pick a blank flange with the Flexicask system. A weldment was fabricated that would imitate the geometry of the GTA so that the test would be as close to the upcoming operations as possible. A problem was quickly identified during this testing. The blank flange used in this testing was slightly larger in diameter than the flange used in FWing. The consequence of this was that the gates and transfer weldment could not fit over the flange without metal-to-metal contact. This required some modifications to the Flexicask design. The diameter of holes in two plates used for each gate needed to be increased. The Transfer Weldment needed to be refabricated with a slightly larger ID. Testing was halted until the new parts were fabricated. 
The modified Flexicask was completed in July 2019, and testing immediately resumed as the GTA testing was complete and waiting on the Flexicask to begin the removal and cleaning process. The modified system fit as designed and rigging and manipulation of the blank flange was successful. Figure 19 shows the blank flange and GTA mock weldment being lifted into the PU shroud. This completed the commissioning of the Flexicask system.

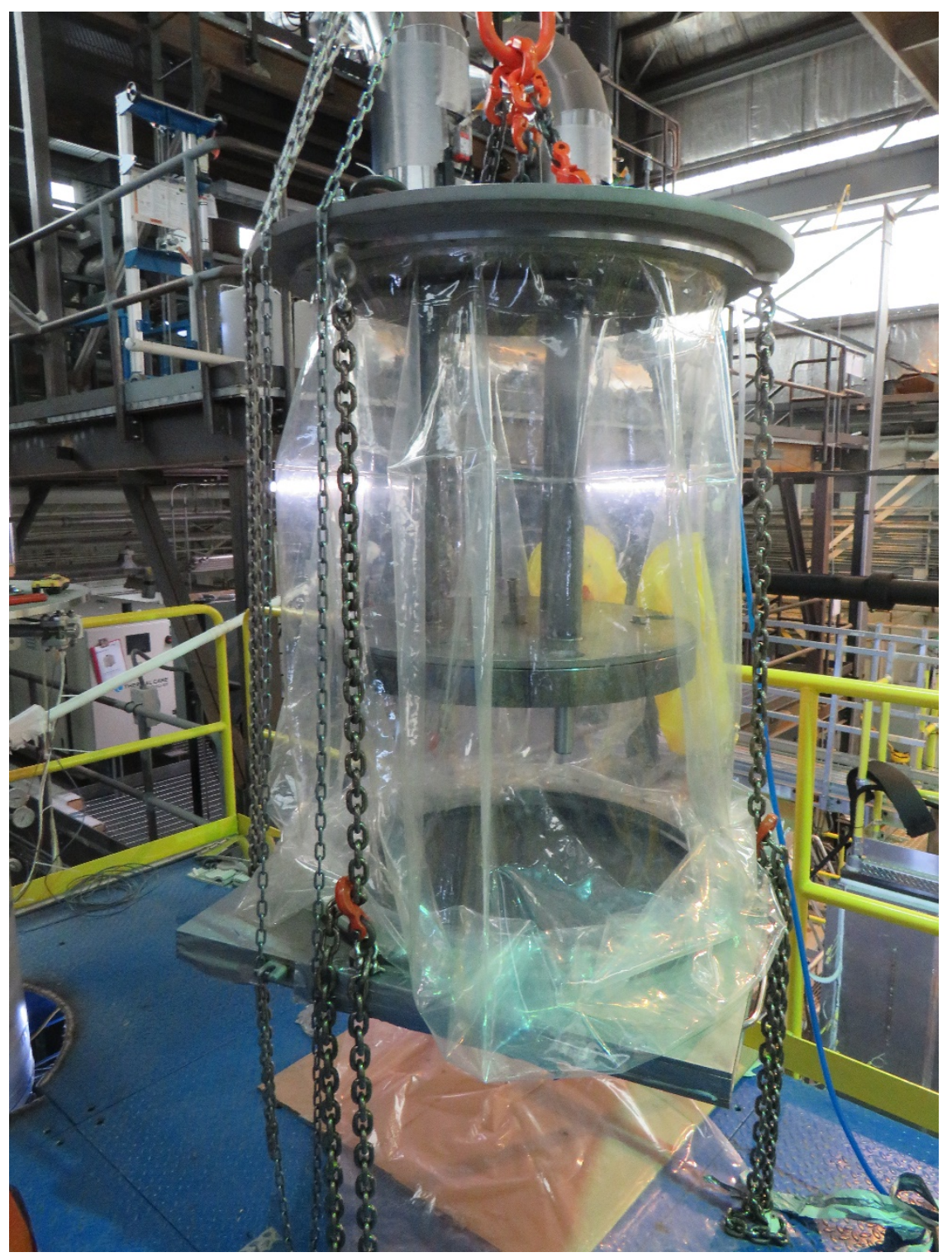

Figure 19 - Flexicask Lifting Blank Flange using the GTA imitator. 


\section{Flexicask Operations - Gear Test Assembly (GTA) Removal}

The first campaign of the GTA operations was completed, and the system needed to be removed from Test Vessel 1 and inserted into the Carbonation System for cleaning. Sodium was drained from Test Vessel 1 and the vessel was allowed to cool to room temperature. The polyurethane shroud on the Flexicask was cut to fit the GTA more accurately, thus making operations easier. The Flexicask was sealed again and passed a leak check, see Figure 20.

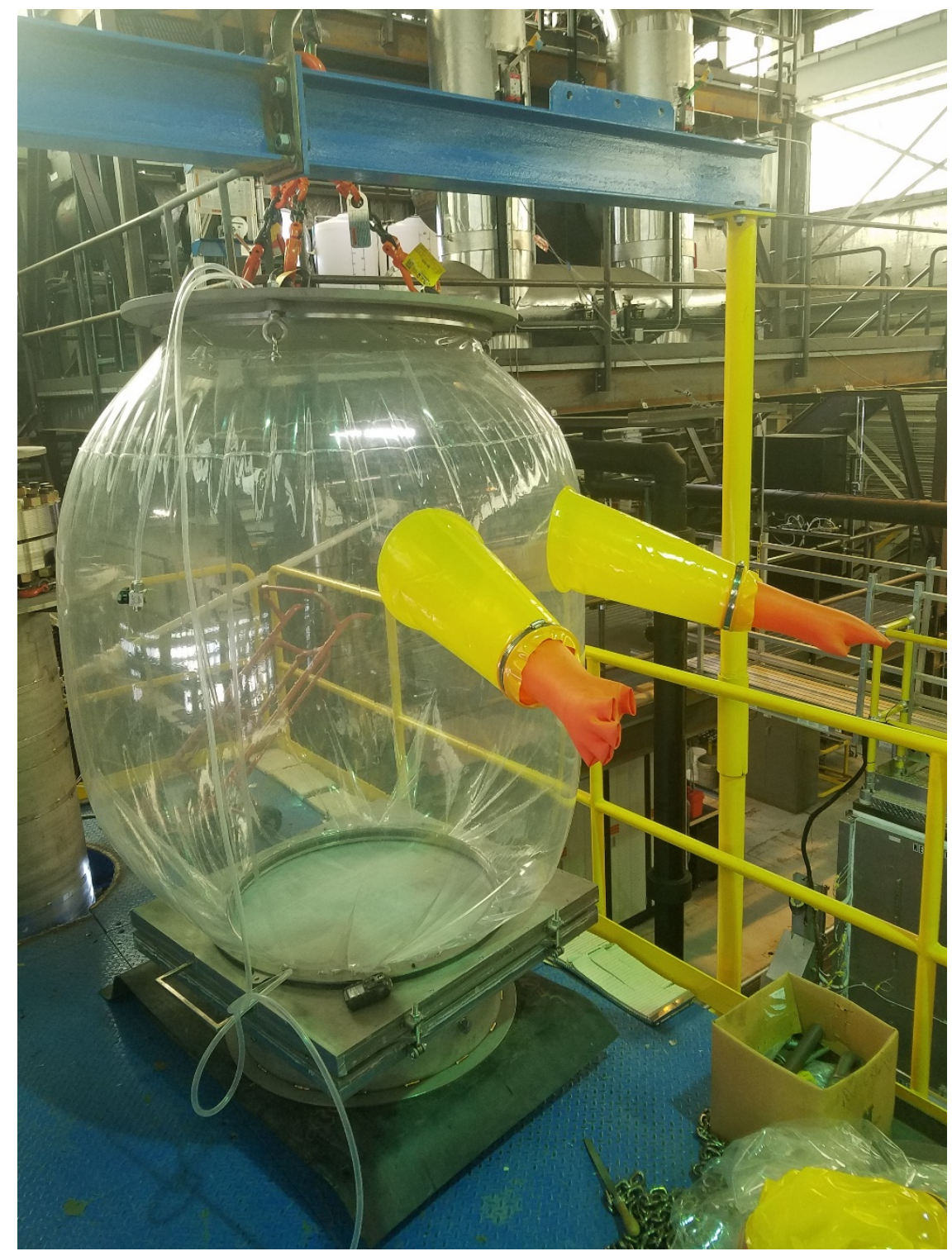

Figure 20 - Flexicask with Polyurethane Shroud sized to GTA. 
Removal operations followed these (simplified) steps:

1. Test Vessel 1 was drained and cooled to room temperature.

2. The blank 18-inch flange on the Carbonation System was removed with the Flexicask and set aside for later.

3. All bolts securing the GTA to Test Vessel 1 were removed.

4. Both gates were removed from the Flexicask.

5. The Flexicask was positioned over the GTA using the overhead crane with an additional manual chain hoist for fine elevation control.

6. The Flexicask was lowered onto the GTA so the custom support plate mated with the GTA properly.

7. Rigging hardware was secured to the GTA to mate the Flexicask to the GTA.

8. An argon purge was initiated at the top port, transfer weldment port, and the test vessel.

9. Oxygen sensors were mounted to the top exhaust, transfer weldment exhaust, and test vessel sample port.

10. Paused until oxygen readings settle at a minimum.

11. The chain hoist was used to carefully lift the GTA into the Flexicask until it cleared the upper gate.

12. Both gates were inserted to isolate the test vessel and isolate the Flexicask.

13. The eye bolts holding the gates together were unfastened and the gates were separated.

14. TheFlexicask and GTA were moved above the Carbonation System.

15. The Flexicask gate was secured to a second transfer weldment positioned on the Carbonation system.

16. Both gates on the Flexicask were removed.

17. The GTA was lowered into the Carbonation system and mounting hardware was removed.

18. The Flexicask was used to pick the blank 18-inch flange with GTA mock weldment.

19. The gate on the Flexicask was inserted and the shroud was inerted with argon.

20. The Flexicask and blank flange were positioned over Test Vessel 1.

21. The Flexicask was lowered and the gates were secured again.

22. Both gates were removed and the blank flange was installed on Test Vessel 1.

23. The Flexicask was removed and prepared for storage. 
The oxygen sensors were closely monitored during these steps and the measurement stayed below 10 ppm throughout, indicating a successful transfer. Table 2 below compares the oxygen concentrations of the preliminary tests to the GTA removal.

Table 2 - Full Flexicask Testing Results.

\begin{tabular}{|l|r|c|c|}
\hline \multicolumn{1}{|c|}{ Case } & \multicolumn{1}{c|}{ A } & B & C \\
\hline 1 & $<50 \mathrm{ppm}$ & $<10 \mathrm{ppm}$ & - \\
\hline 2 & $<10,000 \mathrm{ppm}$ & $<10 \mathrm{ppm}$ & - \\
\hline 3 & $<19 \%$ & $<60 \mathrm{ppm}$ & - \\
\hline 4 & $<19 \%$ & - & $<10 \mathrm{ppm}$ \\
\hline GTA Removal & $<10 \mathrm{ppm}$ & $<10 \mathrm{ppm}$ & $<10 \mathrm{ppm}$ \\
\hline
\end{tabular}

Following are several figures (Figure 21 - Figure 29) depicting the major steps.

The next METL operations with the Flexicask will be to install the GTA back into Test Vessel 1 for additional testing. The procedure for this work is currently being drafted. 


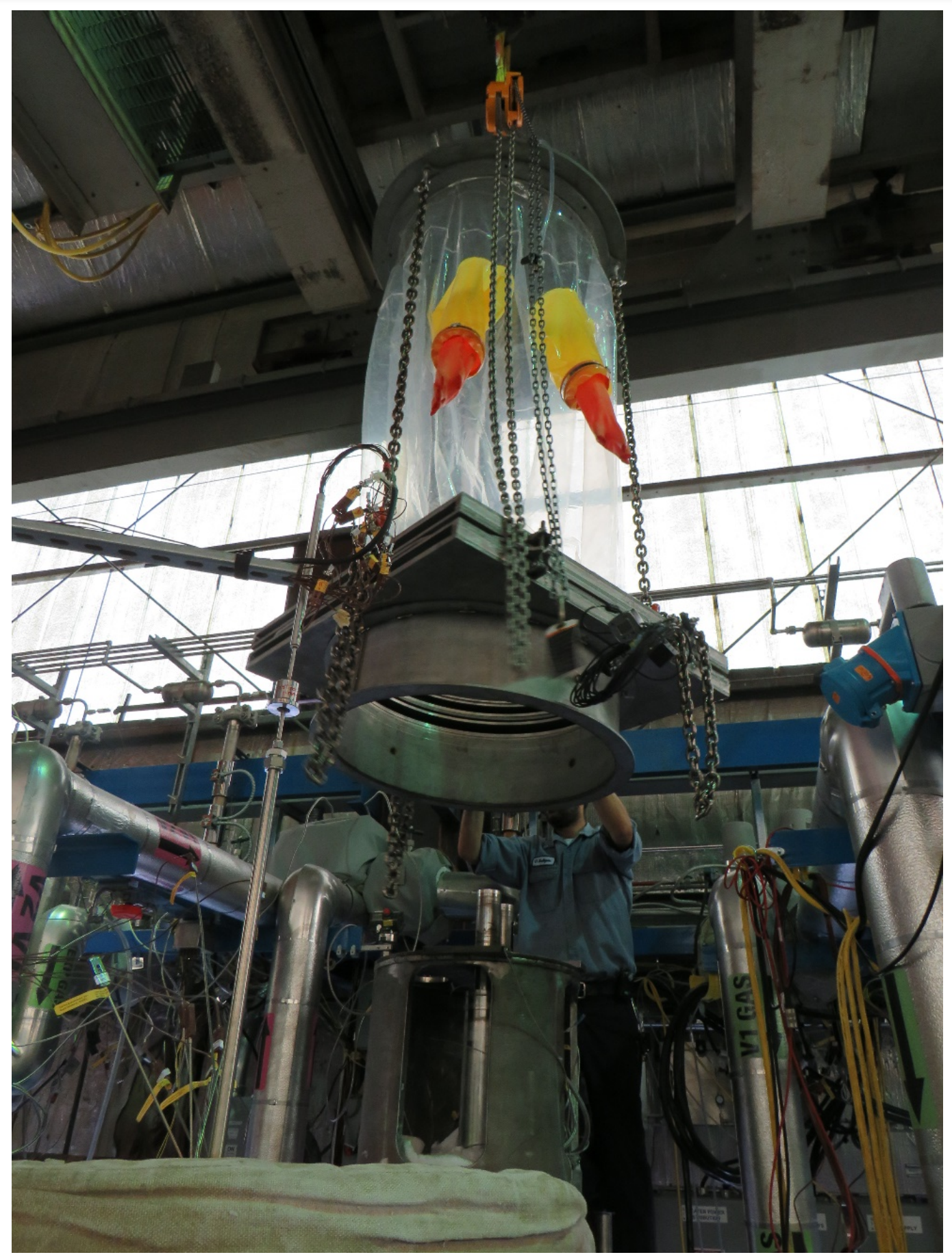

Figure 21 - Flexicask positioned over the GTA. 


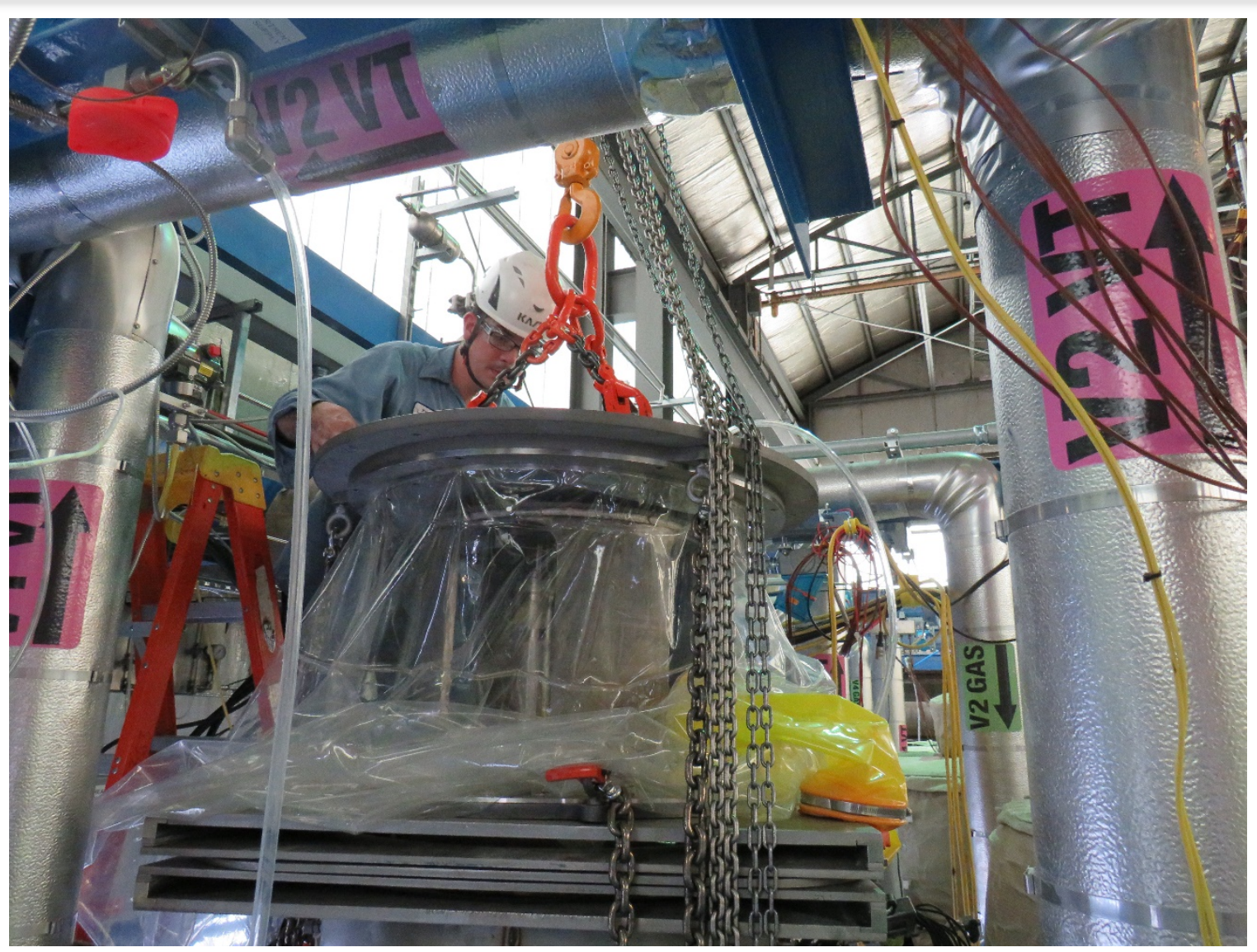

Figure 22 - Flexicask Installed on Test Vessel 1 aligning platen to GTA. 


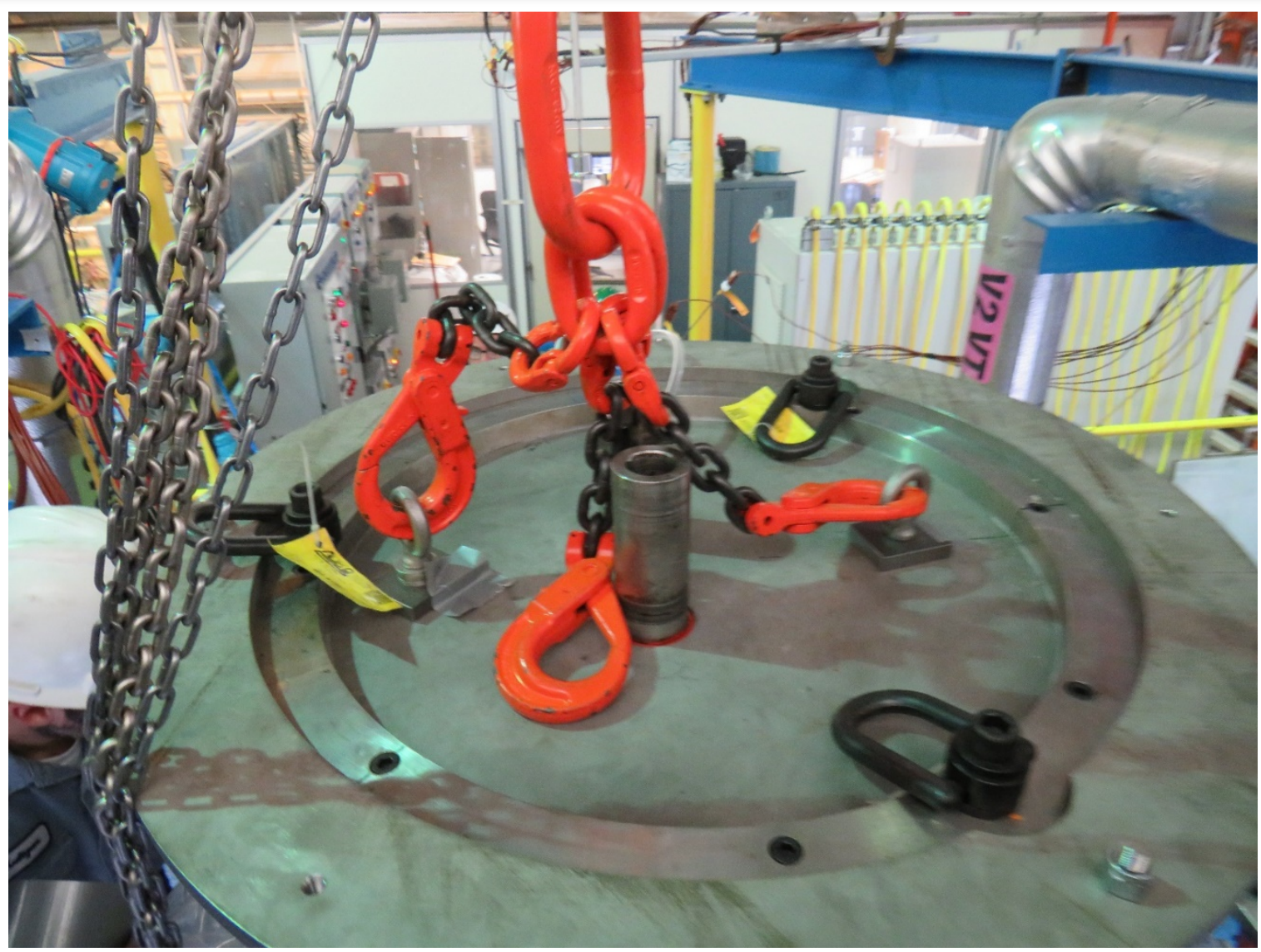

Figure 23 Mounting Hardware Secured through the Flexicask top platen to GTA. Motors and some other components were removed from the GTA prior to this step. 


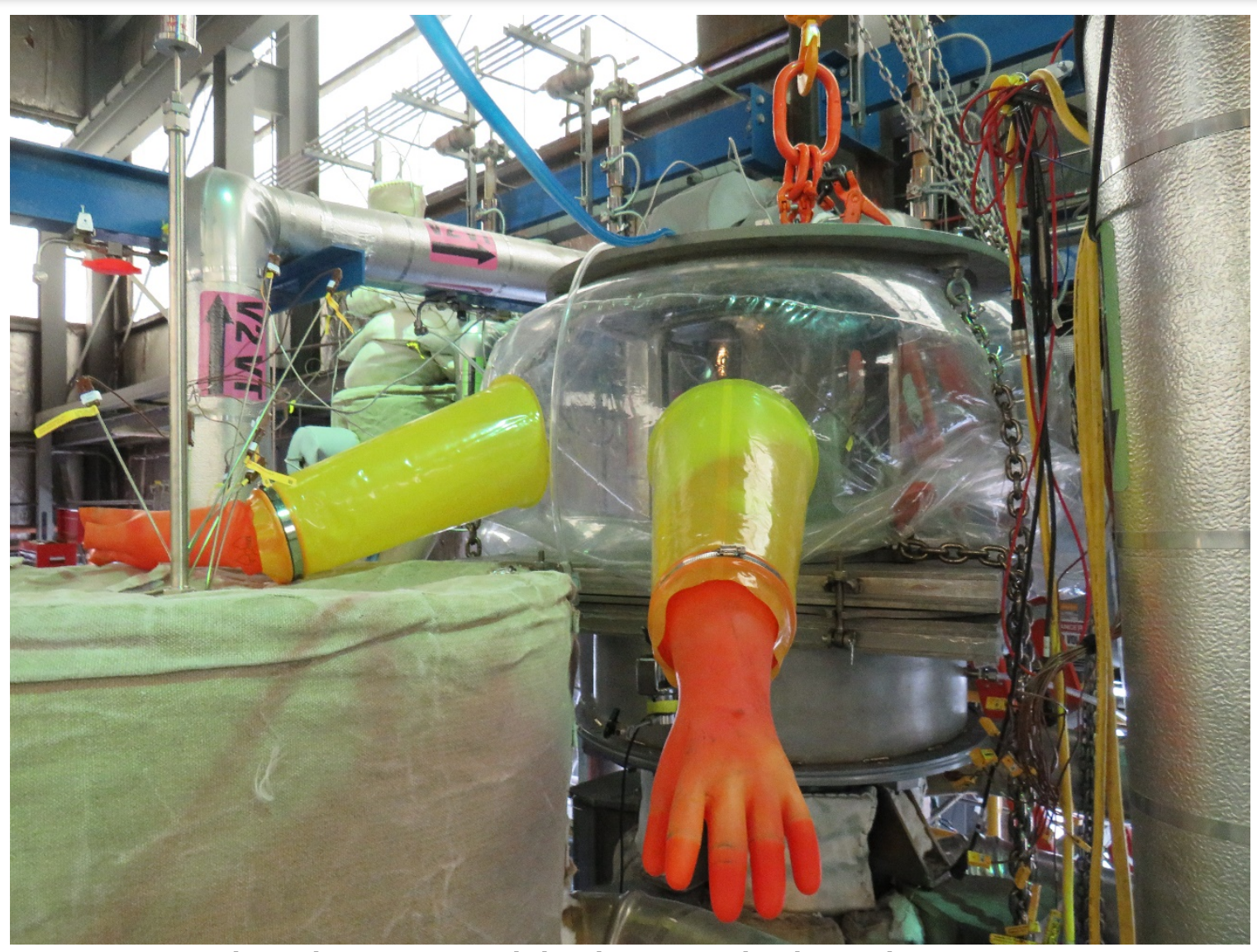

Figure 24 - Flexicask system was sealed to the test vessel and inerted prior to GTA extraction. 


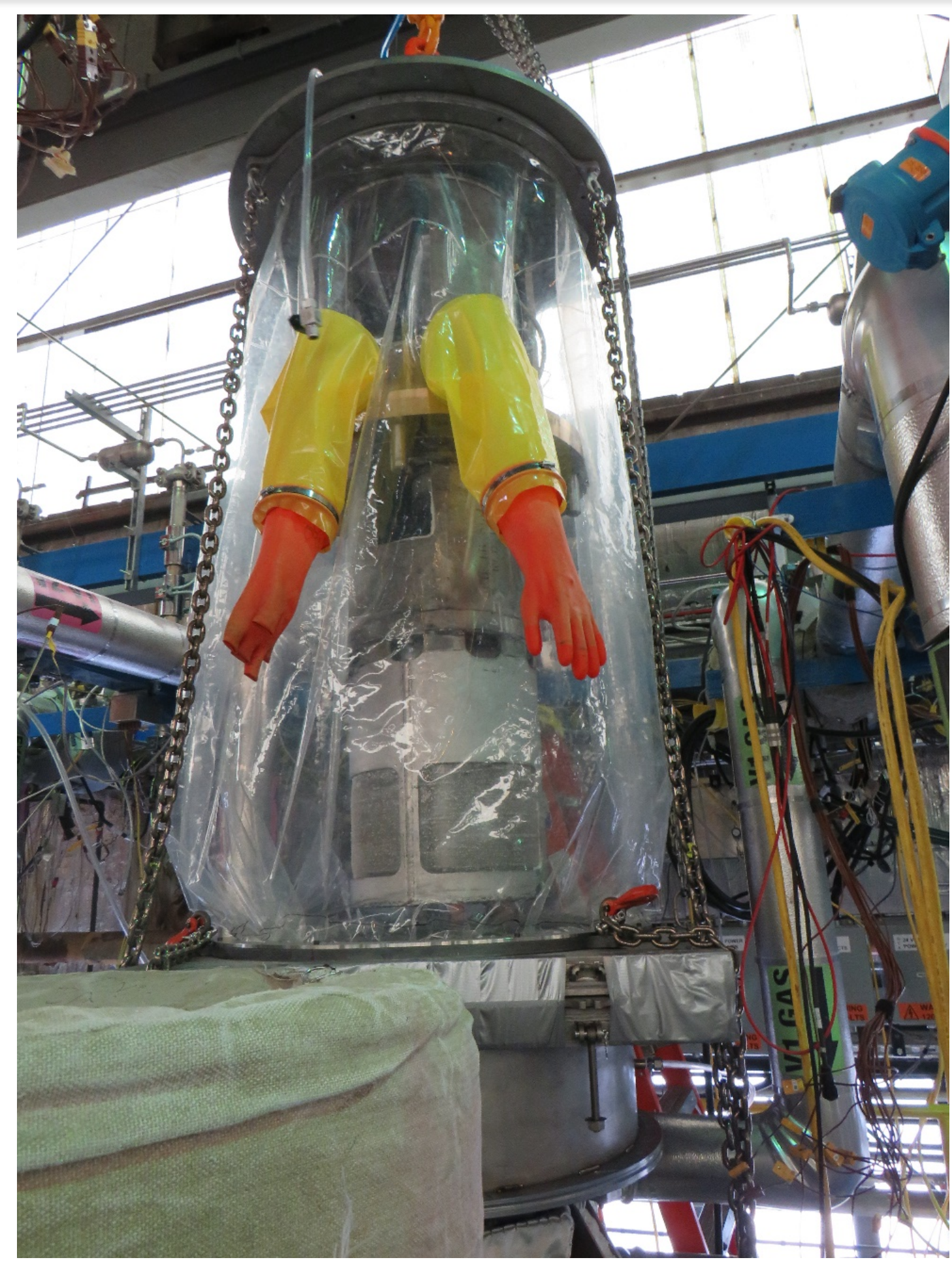

Figure 25 - Flexicask fully extended with GTA fully removed from the 18-inch test vessel and into the inerted shroud (notice there is very little oxidation of the residual sodium). 


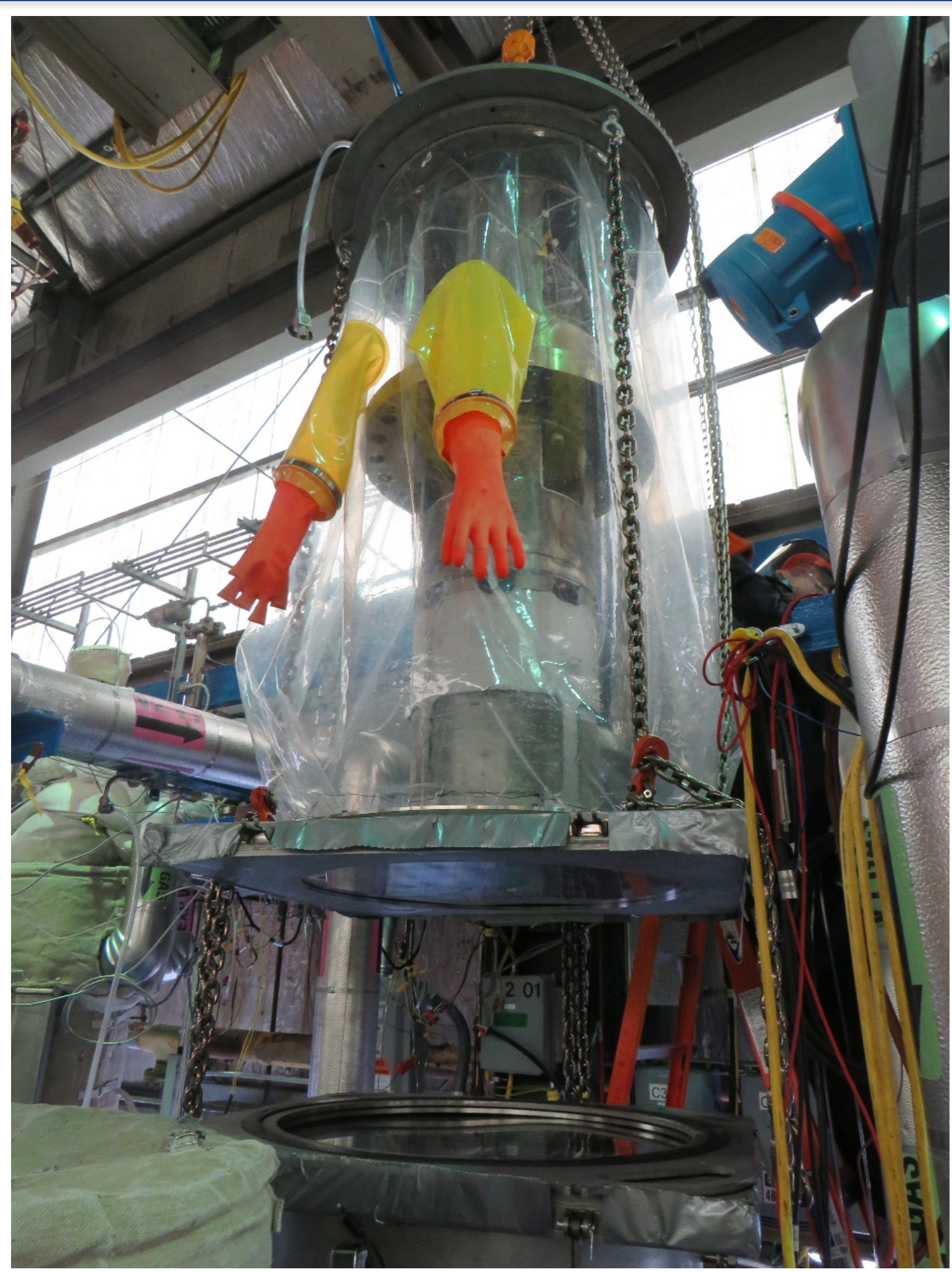

Figure 26 - Flexicask with GTA inside and separated from Test Vessel 1. Both gates are closed maintaining the inert atmosphere inside the flexicask and inside the test vessel. 


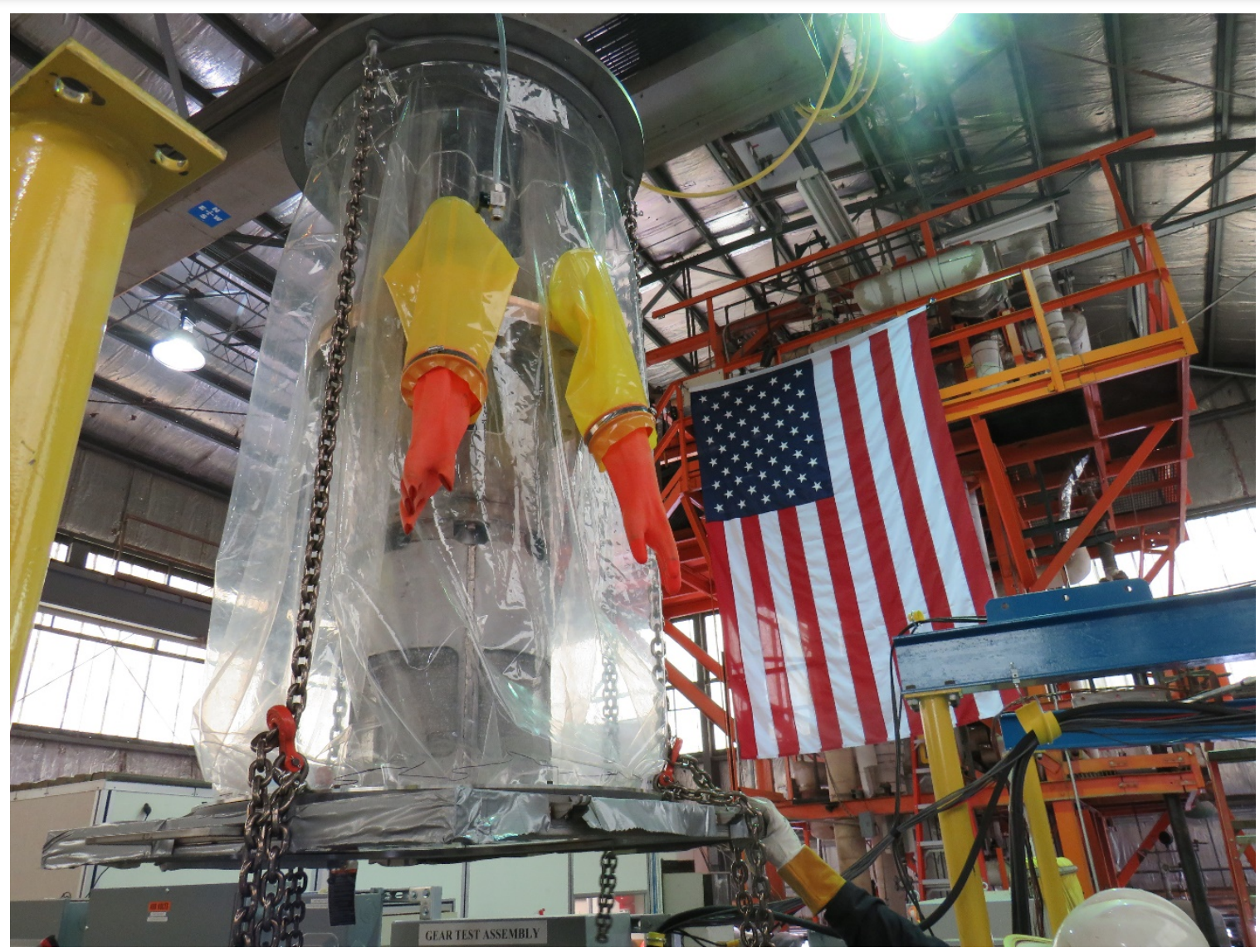

Figure 27 - Flexicask with the GTA in transit to Carbonation System. 


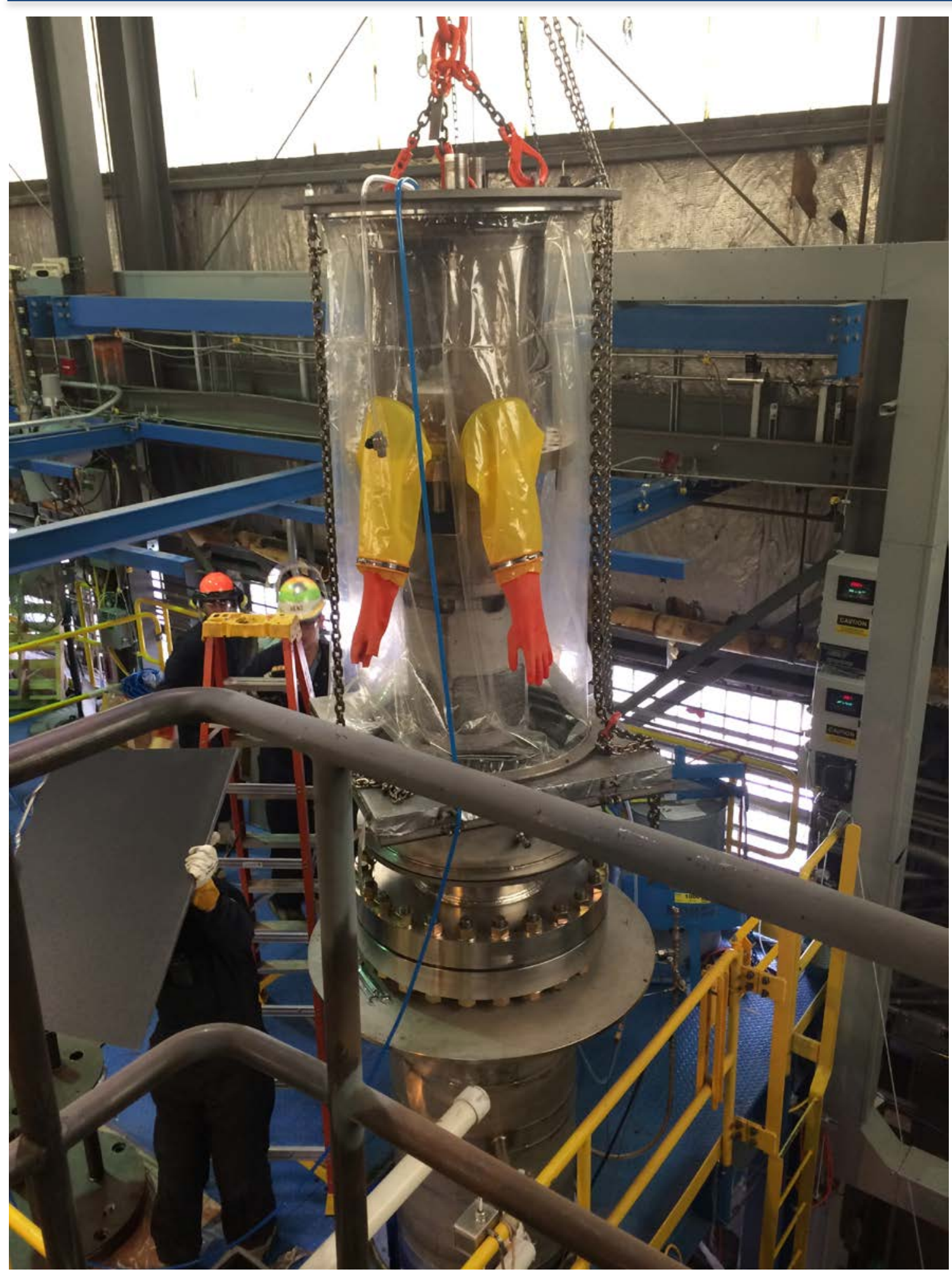

Figure 28 - Flexicask with GTA being positioned over the Carbonation system tank 


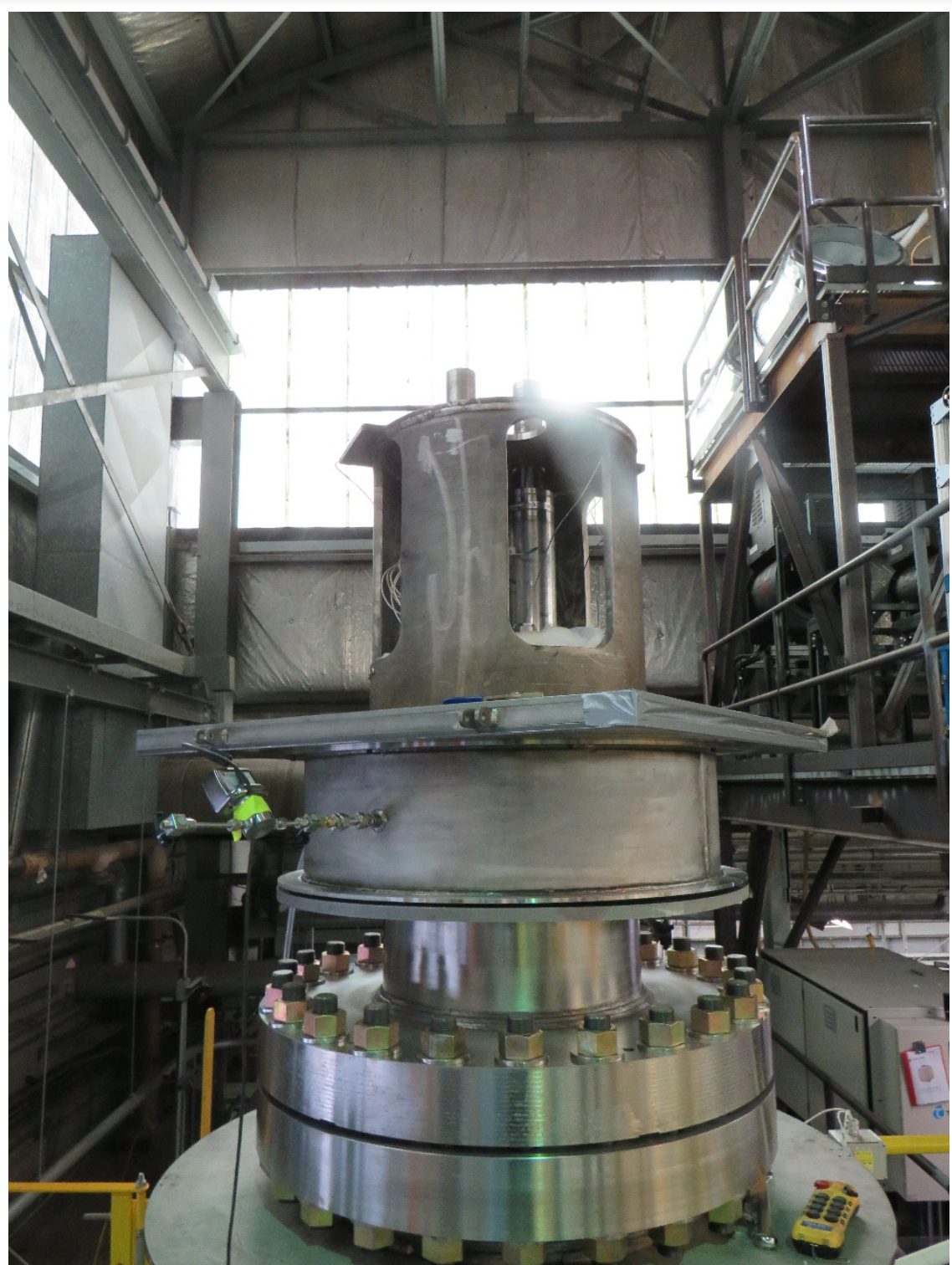

Figure 29 - GTA installed in Carbonation System with the bottom portion of the flexicask shown sealed to the 18-inch to 28-inch adaptor.

On February 26, 2020, the 18-inch flexicask was used for the re-insertion of the GTA back in to Test Vessel 1. The GTA had undergone cleaning, disassembly and inspection, and then reassembly before re-insertion. The difference between the first GTA insertion and this second insertion is that Test Vessel 1 had residual sodium in the vessel which required the use of the flexicask to establish a suitable inert atmosphere during the insertion process.

\subsection{Carbonation System}

When components are removed from METL, they will be covered in frozen sodium residue. In order to safely and gently react away the unwanted sodium, the components will be cleaned using a moist carbonation system. This process was originally developed by Argonne several years ago for the EBR-II deactivation program. 
The P\&ID of the carbonation system that has been built at Argonne can be found in Figure 30 . The carbonation system consists of a $\mathrm{CO}_{2}$ bubbler and reaction chamber. First, a column of water is heated just below its boiling point $\left(\approx 90^{\circ} \mathrm{C}\right)$. Then dry carbon dioxide is pushed through the bottom of the water column to create humid carbon dioxide at the top of the column. Humid carbon dioxide travels through a transfer line in order to carry trace amounts of moisture into the reaction chamber containing the used test articles. The moisture and $\mathrm{CO}_{2}$ react with the sodium residue in one of the two following processes:

$$
\begin{array}{cl}
\mathrm{Na}(\mathrm{s})+\mathrm{CO}_{2}(g)+\mathrm{H}_{2} \mathrm{O}(g) \rightarrow \mathrm{NaHCO}_{3}(\mathrm{~s})+0.5 \mathrm{H}_{2}(g) & \Delta \mathrm{H}^{\circ}{ }_{\mathrm{r}} \approx-313[\mathrm{~kJ} / \mathrm{mol}] \\
2 \mathrm{Na}(g)+\mathrm{CO}_{2}(g)+\mathrm{H}_{2} \mathrm{O}(g) \rightarrow \mathrm{Na}_{2} \mathrm{CO}_{3}(s)+\mathrm{H}_{2}(g) & \Delta \mathrm{H}^{\circ}{ }_{\mathrm{r}} \approx-496[\mathrm{~kJ} / \mathrm{mol}]
\end{array}
$$

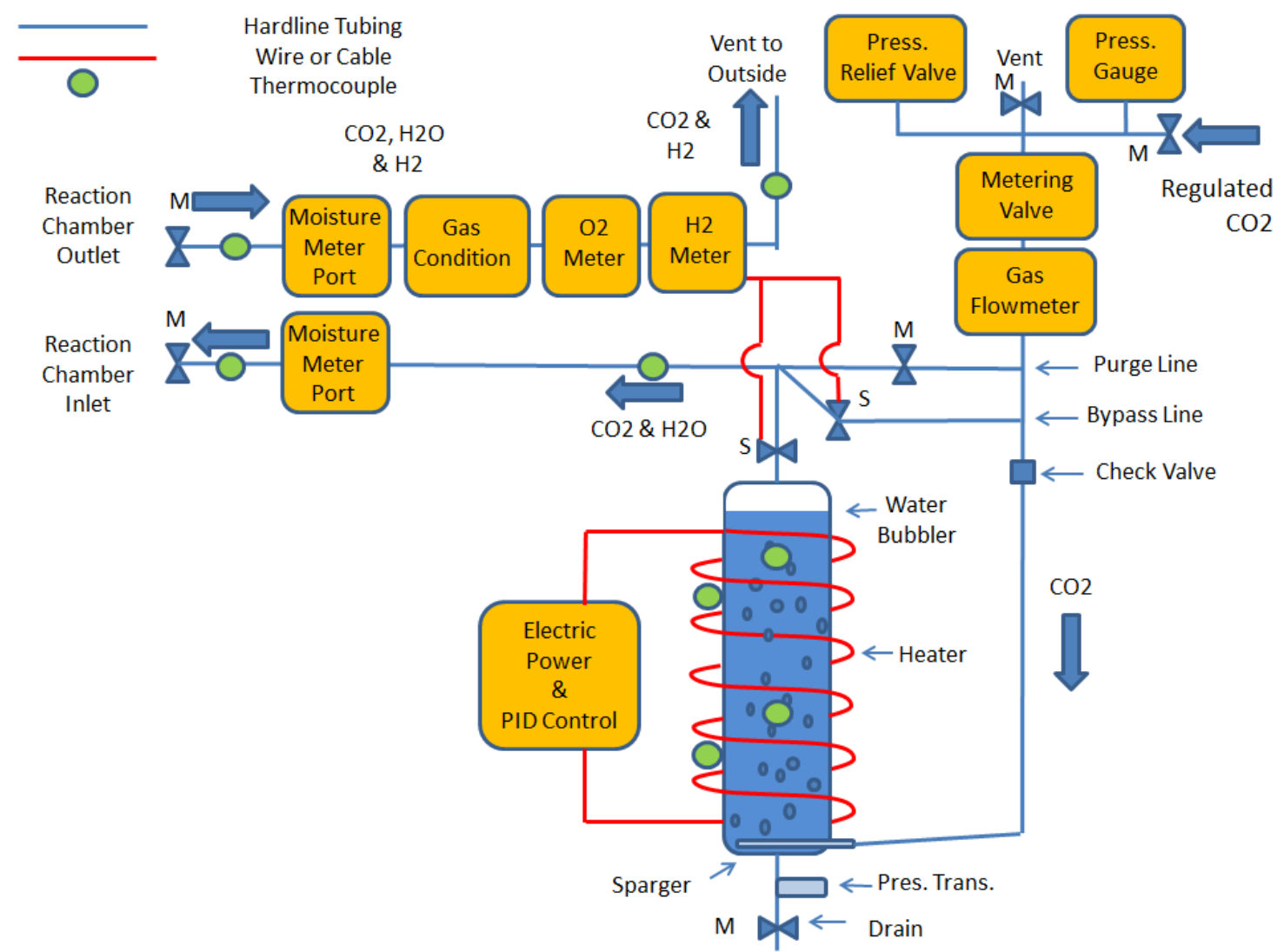

Figure $30-A$ P\&ID for the carbonation system. $(M=$ manual valve, $S=$ solenoid valve $)$.

Figure $31-$ A photo of the completed bubbler for the carbonation system. Carbon dioxide enters through the bottom of the system. Electric heaters are used to raise the temperature of the water to facilitate increasing the humidity of the water ${ }^{8}$.

Reaction chamber supports along with the chamber itself were installed in FY18. The carbon dioxide bubbler was installed on the NSTF mezzanine in B308 and a transfer line was

\footnotetext{
${ }^{8}$ This figure is from Argonne National Laboratory report: M. Hvasta, et.al., "Mechanisms Engineering Test Loop - Phase I Status Report - FY2015, ANL-ART-24, ANL-METL-5, September 2015.
} 
installed connecting the bubbler to the reaction chamber. Lastly, the control system was revitalized to support autonomous operation.

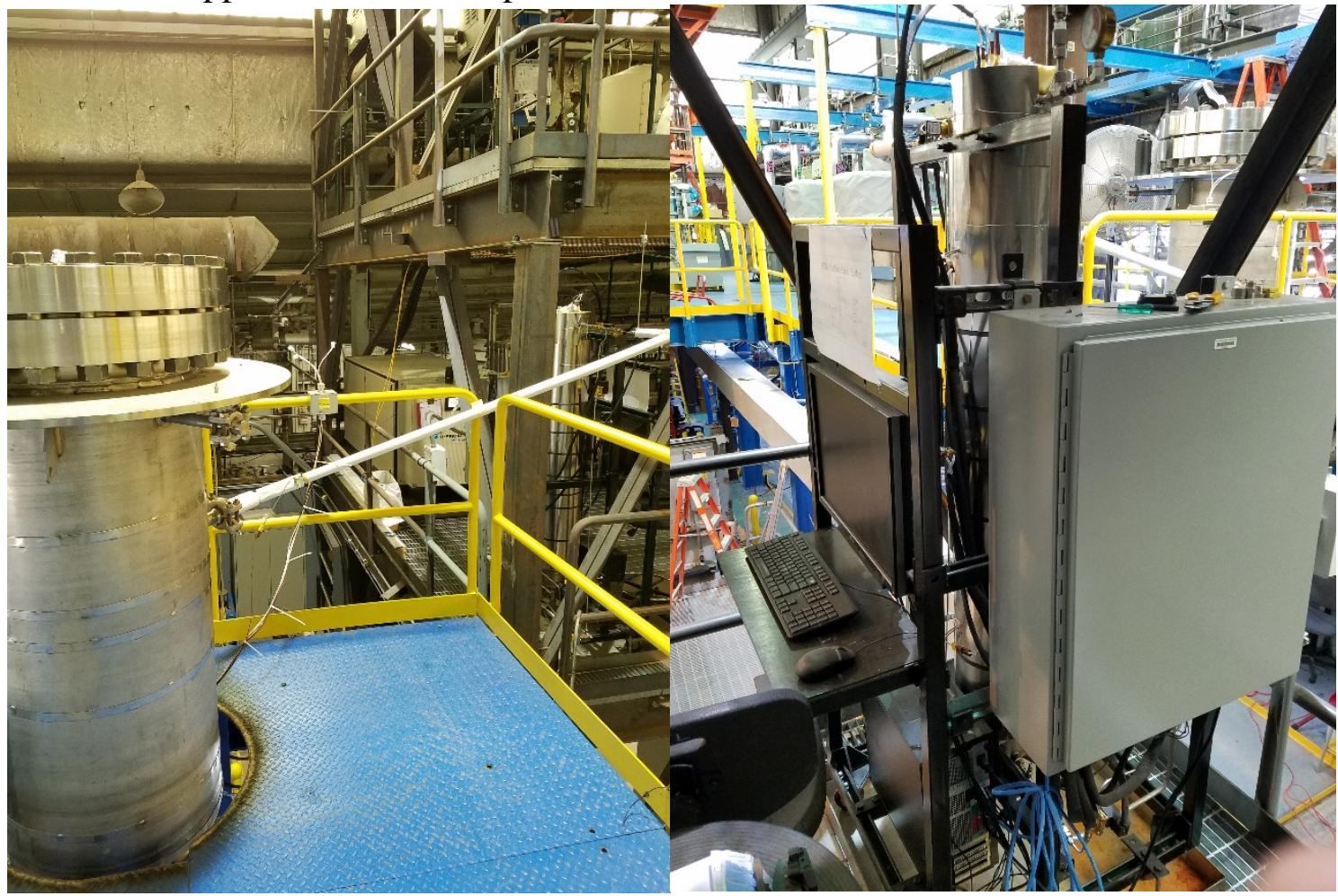

Figure 32 - Reaction Chamber (left) Connected to Bubbler (right)

\section{28-inch Flexicask Development}

The design of the 28-inch flexicask (Figure 33) was accomplished after the design, fabrication, testing, and first use of the 18-inch flexicask. The 28-inch flexicask was then designed taking into account some of the lessons learned associated with the 18-inch flexicask. The 28-inch flexicask is currently in fabrication. 


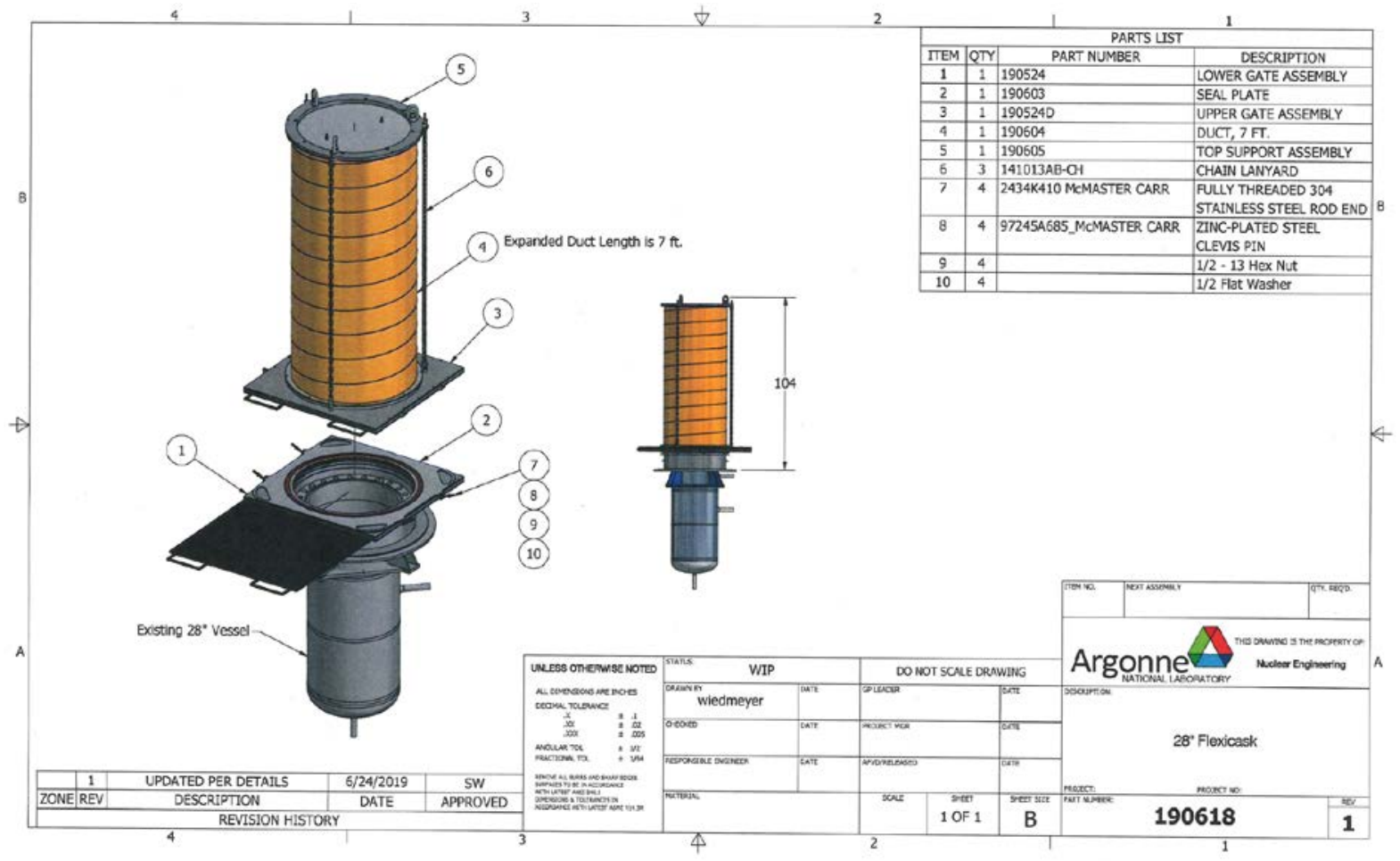

Figure 33 - Design Drawings for 28-inch Flexicask Assembly 


\section{Argonne}

\section{Nuclear Science and Engineering Division}

Argonne National Laboratory

9700 South Cass Avenue, Bldg. 208

Argonne, IL 60439

www.anl.gov 